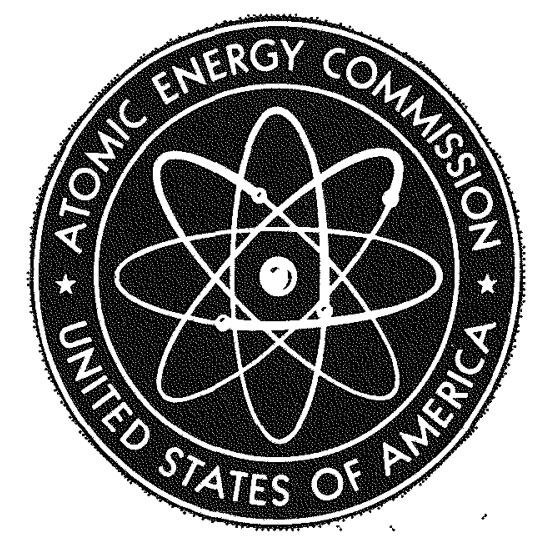

TID-16764

HEALTH AND SAFETY

\title{
A SUMMARY OF INCIDENTS INVOLVING USAEC SHIPMENTS OF RADIOACTIVE MATERIAL, 1957-1961
}

By

D. E. Patterson

V. P. DeFatta

November 1962

[DTI Issuance Date]

Division of Operational Safety

Industrial Safety and Fire Protection Branch, AEC

Washington, D. C. 


\section{LEGAL NOTICE}

This report was prepared as an account of Government sponsored work. Nelther the United States, nor the Commission, nor any person acting on behalf of the Commission:

A. Makes any warranty or representation, expressed or implied, with respect to the accuracy, completeness, or usefulness of the information contained in this report, or that the use of any information, apparatus, method, or process disclosed in this report may not infringe privately owned rights; or

B. Assumes any liablities with respect to the use of, or for damages resulting from the use of any information, apparatus, method, or process disclosed in this report.

As used in the above, "person acting on behalf of the Commission" includes any employee or contractor of the Commission, or employee of such contractor, to the extent that such employee or contractor of the Commission, or employee of such contractor prepares, disseminates, or provides access to, any information pursuant to his employment or contract with the Commission, or his employment with such contractor.

Printed in USA. Price $\$ 0.75$. Avallable from the Office of Technical Services, Department of Commerce, Washington 25, D. C. 


\section{DISCLAIMER}

This report was prepared as an account of work sponsored by an agency of the United States Government. Neither the United States Government nor any agency Thereof, nor any of their employees, makes any warranty, express or implied, or assumes any legal liability or responsibility for the accuracy, completeness, or usefulness of any information, apparatus, product, or process disclosed, or represents that its use would not infringe privately owned rights. Reference herein to any specific commercial product, process, or service by trade name, trademark, manufacturer, or otherwise does not necessarily constitute or imply its endorsement, recommendation, or favoring by the United States Government or any agency thereof. The views and opinions of authors expressed herein do not necessarily state or reflect those of the United States Government or any agency thereof. 


\section{DISCLAIMER}

Portions of this document may be illegible in electronic image products. Images are produced from the best available original document. 
$T 10-16764$

\title{
A SUMMARY OF INCIDENTS \\ INVOLVING \\ USAEC SHIPMENTS OF RADIOACTIVE MATERIAL \\ 1957-1961
}

\author{
By \\ D. E. Patterson \\ and \\ V. P. DeFatta
}

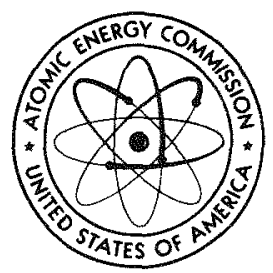

UNITED STATES ATOMIC ENERGY COMMISSION Industrial Safety and Fire Protection Branch Division of Operational Safety 


\section{CONTENTS}

Page

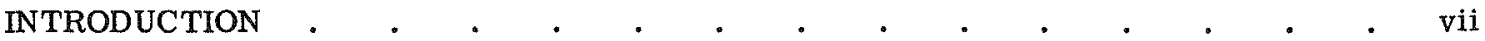

CLASS I RADIATION RELEASE - No Release of Radioactivity $\quad$ • $\quad$ • $\quad$ • $\quad$ • $\quad$ - 1

Truck Transit Incidents

Impact; Collision with Another Vehicle

Case 1, January 22, 1958

Case 2, January 8, 1959

Case 3, November 15, 1960 .

Case 4, December 21, 1960

Impact

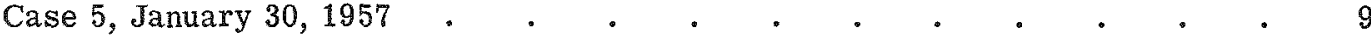

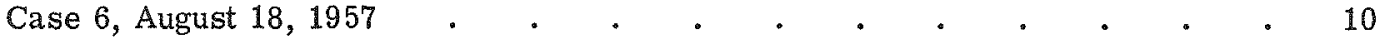

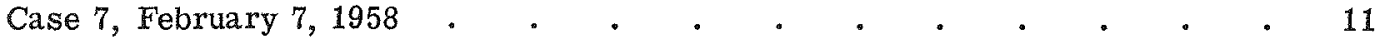

Case 8, March 11, 1960 • . . . . . . . . . . . 12

Fire

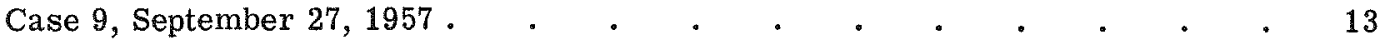

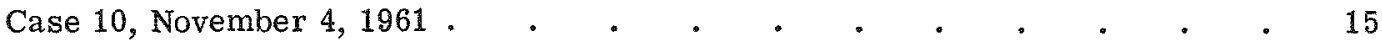

Vehicular Failure

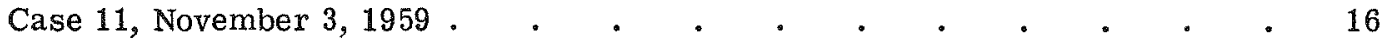

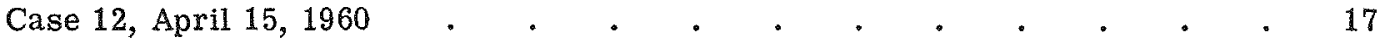

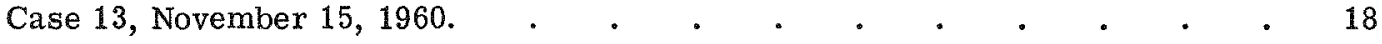

Tiedown Failure

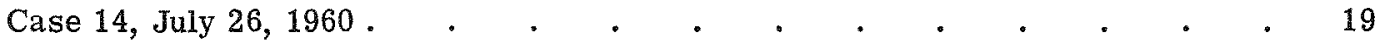

Rail Transit Incidents

Derailment

Case 15, February 19, 1959 . . . . . . . . . . . . 20

Case 16, April 17, 1959 • . . . . . . . . . . . . . . . 21

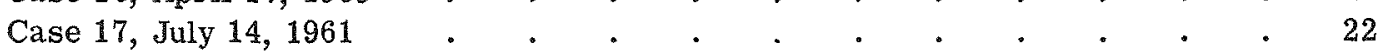

Impact

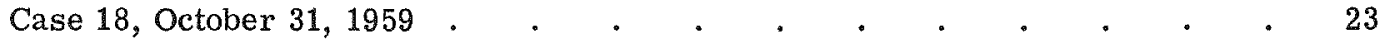

Case 19, December 7,1960 . $\quad . \quad$ • . . . . . . . $\quad$. 25

Fire

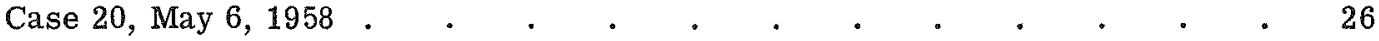

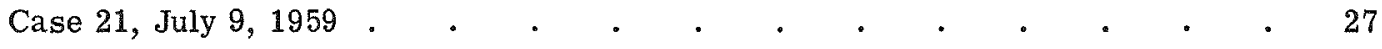


Equipment Failure

Case 22, July 29-30, 1957 .

Leakage En Route

Case 23, July 2, 1959

Terminal Incidents

Truck

Case 24, August 5, 1960

Rail

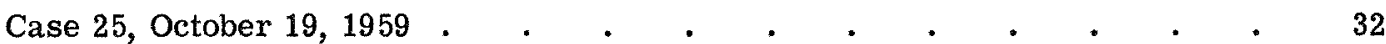

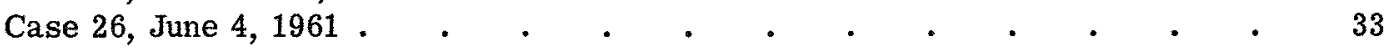

Railway Express Agency

Case 27, May 27, 1961

Air

Case 28, June 23, 1960

Case 29, November 15,1960

CLASS II RADIATION RELEASE - Failure of Container but No Release .

Truck Transit Incidents

Impact

Case 1, December 7, 1961

Fire

Case 2, April 22, 1961

Terminal Incidents

Truck

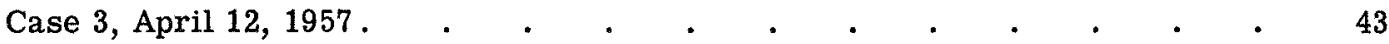

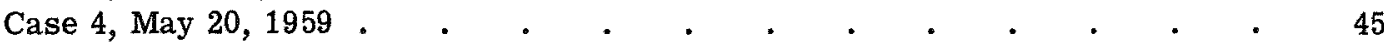

Air

Case 5, July 7, 1959

Case 6, September 2, 1959

Case 7, July 25, 1961

CLASS III RADIATION RELEASE-Release to Vehicle

Truck Transit Incidents

Impact

Case 1, November 20, 1960 .

Tiedown Failure

Case 2, September 22, 1961.

Leakage

Case 3, June 22, 1959 .

Terminal Incidents

Truck

Case 4, July 21, 1959

Case 5, June 15, 1961 . 
Rail

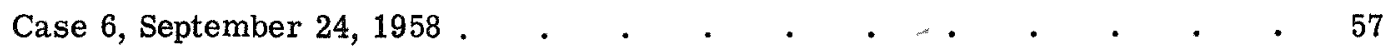

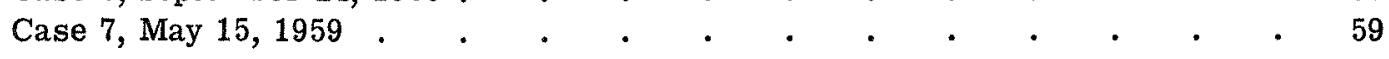

CLASS IV RADIATION RELEASE-Release to Right-of-way . • . • $\quad$ • $\quad$ • 61

Truck Transit Incidents

Vehicular Failure

Case 1, July 1, 1961

Leakage

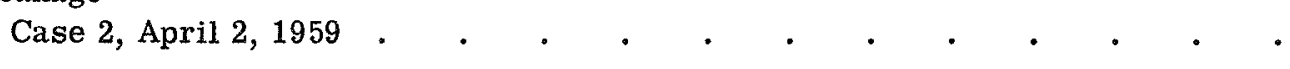

Rail Transit Incident

Leakage

Case 3, June 2-6, 1960 .

CLASS V RADIATION RELEASE-Release to Atmosphere

Rail Transit Incident

Aerial Dispersal

Case 1, January 4, 1958

CLASS VI RADIATION RELEASE - Release to a Water Supply 71

\section{LIST OF TABLES}

Table 1-Summary of Annual AEC Shipments of Radioactive Materials

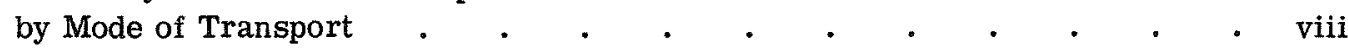

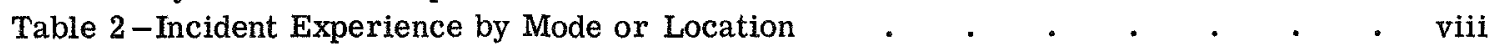

Table 3 -Incident Experience by Class of Radiation Release . . . . . • . $\quad$. viii

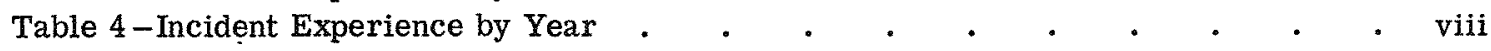
Table 5-Incident Experience; Frequency by Months Irrespective of Years . $\quad . \quad$ ix Table 6-Incident Experience by Type, Irrespective of Mode (unless specified) . $\quad$. ix

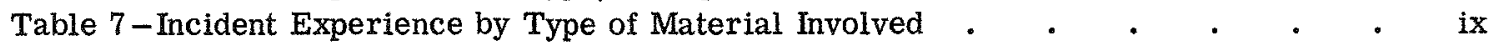




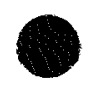

•<smiles>CCCC</smiles>

$\checkmark$

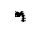

.

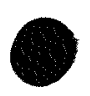




\section{INTRODUCTION}

This summary has been prepared to present information pertaining to incidents which have been sustained by the AEC in the transportation of radioactive materials. The incidents presented herein cover the period from 1957 through 1961. A previous document, AECU-3613, "A Summary of Transportation Incidents in Atomic Energy Activities, 1949-1956," reviewed earlier experience.

In the period covered by this report, January 1, 1957 through December 31, 1961, there were forty-seven incidents reported. Twenty-nine $(61.7 \%)$ of the forty-seven incidents did not result in release of radioactive materials. Of the remaining eighteen cases, which did involve radiation releases, there were none that presented any serious consequences or involved costly cleanup. Six of the incidents involved shipments which were strictly onsite movements.

In this summary, the incidents have been classified in accordance with the type of radiation release that occurred. This follows a method suggested by Morgan, Knapp, and Thompson of Johns Hopkins University in "A Study of the Possible Consequences and Costs of Accidents in Transportation of High Level Radioactive Material." The classification scheme is as follows:

1. Class I Radiation Release. The vehicle has been involved in an accident or package damage is suspected. The shipment is delayed or stopped. No radioactive material is released and there is actually no loss of integrity to the package.

2. Class II Radiation Release. The package integrity is breached. However, there is no release of radioactive materials.

3. Class III Radiation Release. Radioactive material is released, but is confined to the package or the vehicle.

4. Class IV Radiation Release. Radioactive material is released to the ground or trafficway with no runoff or aerial dispersal.

5. Class $V$ Radiation Release. Radioactive material is released, resulting in aerial dispersal.

6. Class VI Radiation Release. Radioactive material is released and enters a watercourse, either directly or after spilling to the ground or trafficway.

This scheme of classification was chosen because it was found that all of the incidents would fit into one of the six classes, and it represents a reasonable approach to delineating radiation release according to the potential consequences.

Within classes of radiation release, the incidents are subdivided according to mode of transport (truck, rail, or air) or location (terminals). The incidents are further subdivided within modes according to types of incident (impact, fire, etc.) and finally, chronologically within types of incidents. 
Table 1-SUMMARY OF ANNUAL AEC SHIPMENTS OF

RADIOACTIVE MATERIALS BY MODE OF TRANSPORT*

\begin{tabular}{|c|c|c|}
\hline Mode of Transport & Number $\dagger$ & $\%$ Total \\
\hline Truck & 16,500 & 35.6 \\
\hline Rail Freight & 7,000 & 15.1 \\
\hline Railway Express & 11,100 & 24.0 \\
\hline Air & 11,800 & 25.3 \\
\hline Total & 46,400 & $100 \%$ \\
\hline
\end{tabular}

* This summary includes information concerning AEC shipments only, and is based on data covering a sixmonth period from October 1, 1961 through March 31, 1962.

$\dagger$ Represents total number of individual packages.

Table 2-INCIDENT EXPERIENCE BY MODE OR LOCATION

\begin{tabular}{lc}
\hline \multicolumn{1}{c}{ Mode } & No. of Incidents \\
\hline Truck Incidents & 21 \\
Rail Incidents & 11 \\
Terminal Incidents & 15 \\
& Total $\frac{47}{47}$ \\
\hline
\end{tabular}

Table 3-INCIDENT EXPERIENCE BY

CLASS OF RADIATION RELEASE

\begin{tabular}{|c|c|}
\hline Class & No. of Incidents \\
\hline I & 29 \\
\hline II & 7 \\
\hline III & 7 \\
\hline IV & 3 \\
\hline $\mathrm{V}$ & 1 \\
\hline \multirow[t]{2}{*}{$\mathrm{VI}$} & 0 \\
\hline & Total $\overline{47}$ \\
\hline
\end{tabular}

Table 4-INCIDENT EXPERIENCE BY YEAR

\begin{tabular}{cc}
\hline Year & No. of Incidents \\
\hline 1957 & 6 \\
1958 & 5 \\
1959 & 15 \\
1960 & 12 \\
1961 & $\frac{9}{47}$ \\
& Total \\
& \\
& viii
\end{tabular}


Table 5-INCIDENT EXPERIENCE BY MONTHS IRRESPECTIVE OF YEARS

\begin{tabular}{lc}
\hline Month & No. of Incidents \\
\hline January & 4 \\
February & 2 \\
March & 2 \\
April & 5 \\
May & 3 \\
June & 5 \\
July & 9 \\
August & 2 \\
September & 4 \\
October & 2 \\
November & 6 \\
December & 3 \\
& Total \\
\hline
\end{tabular}

Table 6-INCIDENT EXPERIENCE BY TYPE, IRRESPECTIVE OF MODE

(Unless specified)

\begin{tabular}{|c|c|c|}
\hline Type & \multicolumn{2}{|c|}{ No. of Incidents } \\
\hline Handling (in Terminals) & & 15 \\
\hline Impact (Collision) & & 12 \\
\hline Fire & & 5 \\
\hline Vehicle or Equipment Failure & & 5 \\
\hline Leakage of Containers & & 4 \\
\hline Derailment (Rail) & & 3 \\
\hline Tiedown Failure & & 2 \\
\hline \multirow[t]{2}{*}{ Aerial Dispersal } & & 1 \\
\hline & Total & 47 \\
\hline
\end{tabular}

Table 7-INCIDENT EXPERIENCE BY TYPE OF MATERIAL INVOLVED

\begin{tabular}{lc} 
Type of Material & $\begin{array}{c}\text { No. of } \\
\text { Incidents }\end{array}$ \\
\hline Source Material & 14 \\
Radioisotopes & 10 \\
Irradiated Fuel Elements & 8 \\
Special Nuclear Material & 4 \\
Radioactive Waste & 3 \\
Empty Containers & 3 \\
Contaminated Machinery & 3 \\
Unknown & 2 \\
& Total \\
\hline
\end{tabular}




\section{CLASS I RADIATION RELEASE}

The vehicle has been involved in an accident or package damage is suspected. The shipment is delayed or stopped. No radioactive material is released and there is actually no loss of integrity to the package. 
-

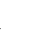




\section{CLASS I}

\section{CASE 1}

Description of Operation

Truck shipment of source material

Nature of Incident

Impact; collision with pickup truck

Date: January 22, 1958

Type of Radioactive Material Involved

Uranium hexafluoride

Radiation Consequences of Incident

None

Details of the Incident

A tractor-trailer carrying the uranium hexafluoride, upon passing through an intersection, collided with a pickup truck which had not stopped for a stop sign at the intersection.

Nature of Injuries or Loss

The occupants of the pickup truck suffered minor injuries. Damage to the tractor-trailer amounted to $\$ 500$; repair cost of the pickup truck was $\$ 800$. The shipment was delayed several hours. 







\section{CLASS I}

\section{CASE 2}

Description of Operation

Truck shipment of source material

Nature of Incident

Impact; collision with passenger train

Date: January 8, 1959

Type of Radioactive Material Involved

Normal assay uranium tetrafluoride

Radiation Consequences of Incident

None

Details of the Incident

The truck, containing the $\mathrm{UF}_{4}$ in three five-ton hoppers, was hit by a passenger train at a rail crossing. The train (a diesel-powered passenger train) was traveling at an estimated speed of 30-40 mph when it struck the left rear side of the trailer approximately one foot from the rear of the trailer.

Nature of Injuries or Loss

No one was hurt and none of the containers were broken open or damaged. There was a slight damage to the diesel engine. The trailer was damaged in the rear and the frame was bent, but was still roadworthy. 







\section{CLASS I}

\section{CASE 3}

Description of Operation

Truck shipment of irradiated fuel elements

Nature of Incident

Impact; collision with station wagon

Date: November 15,1960

Type of Radioactive Material Involved

Fission products contained in twenty-five irradiated fuel elements

Radiation Consequences of the Incident

The fuel elements contained in seven steel-jacketed lead casks were undisturbed

Detaits of the Incident

A combination of bumps in the road and a slippery condition resulting from a light drizzle caused the tractor-trailer to skid and go into a partial jackknife. The tractor-trailer crossed over into the opposite lane and struck an approaching station wagon near the front left-hand door.

Nature of Injuries or Loss

The station wagon was completely demolished and the driver was killed. The tractor was damaged badly and the truck driver suffered a broken hand and abrasions. Value of station wagon $-\$ 125$, damage to tractor $-\$ 1,950$, which represents total loss, less salvage of the tractor. 


\section{CLASS I}

\section{CASE 4}

Description of Operation

Truck shipment of special nuclear material

Nature of Incident

Impact; collision with tractor-trailer

Date: December 21, 1960

Type of Radioactive Material Involved

Uranium oxide $\left(\mathrm{UO}_{3}\right)$ and uranium hexafluoride $\left(\mathrm{UF}_{6}\right)$

Radiation Consequences of the Incident

Although the hoppers containing the materials were thrown from the trailer, the hoppers remained intact and there was no spillage.

Details of the Incident

During a bad sleet storm, two tractor-trailers were following one another, the first carrying $\mathrm{UO}_{3}$ in three five-ton hoppers, and the second carrying $\mathrm{UF}_{6}$. The first driver, after topping a hill, noted headlights on both sides of the roadway from vehicles that had swerved off the road. He managed to get the trailer through the cars, but the trailer jackknifed and two of the hoppers rolled off the trailer and into a ditch. The second tractor-trailer also negotiated the two cars, but could not stop, and collided with the jackknifed trailer, knocking the third hopper into the ditch.

Nature of Injuries or Loss

There were no personnel injuries; however, there was a 12-hour delay in the shipment, damage to the two rigs, and a wrecker with crew had to be dispatched to reload the hoppers. Cost of retrieving equipment was $\$ 138$. 


\section{CLASS I}

\section{CASE 5}

Description of Operation

Truck shipment of source material

Nature of Incident

Impact and overturn

Date: January 30, 1957

Type of Radioactive Material Involved

Depleted assay uranium hexafluoride contained in a 10-ton cylinder

Radiation Consequences of Incident

None

Details of Incident

While driving in a heavy snowstorm which had obscured the highway, the vehicle driver inadvertently eased his tractor-trailer onto the right-hand shoulder of the road. The shoulder of the road had softened to the extent that the driver could not return the vehicle to the paved highway, and after traveling approximately 396 feet on the shoulder, the rig came to rest against an embankment, turning over on its right side.

Nature of Injuries or Loss

The tractor had a bent fender and stripped transmission gears. The right half of the windshield was broken. The shipment was delayed several hours while another vehicle was obtained to transport the cylinder. Cost to restore tractor to operational condition was $\$ 750$. 


\section{CLASS I}

\section{CASE 6}

Description of Operation

Truck shipment of source material

Nature of Incident

Impact

Date: August 18, 1957

Type of Radioactive Material Involved

Uranium hexafluoride

Radiation Consequences of the Incident

None

Details of the Incident

During transport of materials, a tractor-trailer left the highway and ran into a ditch which paralleled the highway. The cause of the accident was attributed to an act of misjudgment on the part of the vehicle driver.

Nature of Injuries or Loss

No damage to equipment or shipment. Shipment was delayed and cost of retrieving equipment was $\$ 60$. 


\section{CLASS I}

\section{CASE 7}

Description of Operation

Truck shipment of special nuclear material

Nature of Incident

Impact and overturn

Date: February 7, 1958

Type of Radioactive Material Involved

Uranium hexafluoride $\left(\mathrm{UF}_{6}\right)$

Radiation Consequences of the Incident

None

\section{Details of the Incident}

The tractor-trailer containing the $\mathrm{UF}_{6}$ shipment was forced to pull off the roadway and onto the shoulder of the road and stop because the road was blocked by an automobile that had skidded and hit an abutment. The shoulder of the road had become softened due to thaw, gave way and caused the tractor-trailer to turn over.

Nature of Injuries or Loss

The shipment was delayed several hours, cost of retrieving the tractor-trailer and cylinder was $\$ 280$, and repair damage to the carrier amounted to $\$ 300$. 


\section{CLASS I}

\section{CASE 8}

Description of Operation

Truck shipment of special nuclear material

Nature of Incident

Impact and overturn

Date: March 11, 1960

Type of Radioactive Material Involved

Uranium hexafluoride $\left(\mathrm{UF}_{6}\right)$ in a 10 -ton cylinder

Radiation Consequences of the Incident

None. The $U F_{6}$ container remained intact and there was no radioactive leakage or spillage.

Details of the Incident

A tractor-trailer truck, carrying a 10-ton cylinder of $\mathrm{UF}_{6}$, skidded and overturned on an icy highway, after rounding a curve. A recovery crew was sent to the scene and another truck was required to continue on with the shipment.

Nature of Injuries or Loss

No personnel injuries occurred. The shipment was delayed and the tractor-trailer suffered some damage. A survey team and recovery team had to be dispatched to the scene. Cost of retrieving equipment was $\$ 165$. 


\section{CLASS I}

\section{CASE 9}

Description of Operation

Truck shipment of source material

Nature of Incident

Fire

Date: September 27, 1957

Type of Radioactive Material Involved

4,300 kilograms of uranium packed in 90 wooden boxes

Radiation Consequences of the Incident

The cargo was undisturbed; no radiation consequences were encountered.

Details of the Incident

Near the outskirts of a city, the couriers accompanying the shipment noted smoke coming from beneath the trailer. The truck was stopped and the couriers extinguished the blaze with fire extinguishers which were in the escort vehicle. The cause of the fire was attributed to friction heat generated by a partially set emergency brake. The excessive heat, in turn, caused accumulated grease and oil in the emergency brake housing to ignite.

Nature of Injuries or Loss

The blaze was extinguished and the convoy was on its way within 20 minutes. 


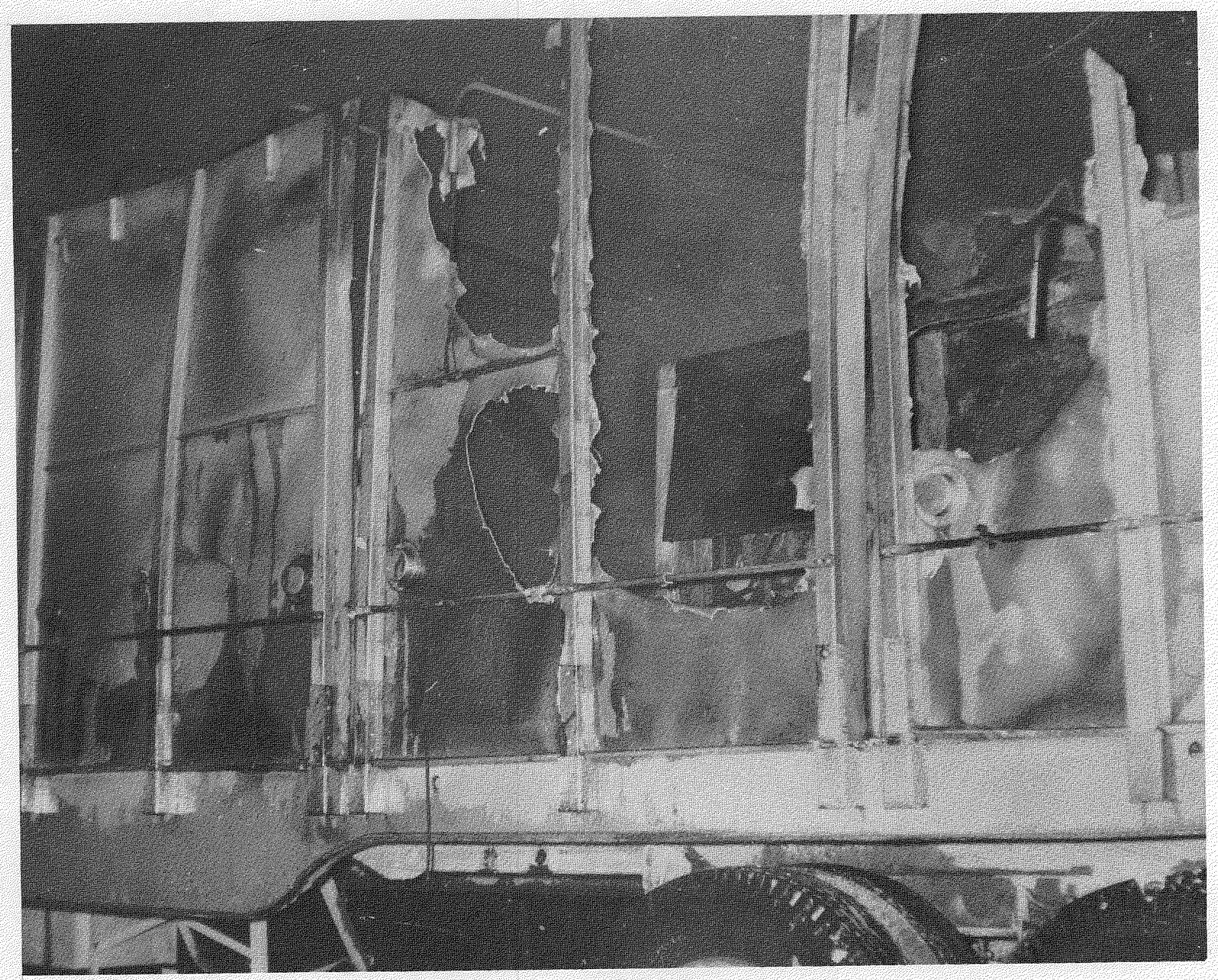




\section{CLASS I}

\section{CASE 10}

Description of Operation

Truck shipment of source material

Nature of Incident

Fire

Date: November 4, 1961

Type of Radioactive Material Involved

Metallic uranium

Radiation Consequences of the Incident

The radioactive material was undamaged and there was no release

Details of the Incident

Fire was first detected by the truck driver of the lead vehicle, who observed a trace of smoke emanating from the trailer. The truck was immediately halted and the tractor uncoupled, while the local fire department was summoned. Fire extinguishers from the escort vehicle were used by the couriers to combat the blaze. The local fire department responded promptly, and, with their aid, the blaze was extinguished in approximately 15 minutes.

Part of the cargo was a gasoline-powered generator. While it could not be determined that this was the source, the possibility exists that a spark could have originated from the starter battery and started the fire.

Nature of Injuries or Loss

A radiological assistance team proceeded to the scene of the accident and determined that no radiation hazard had occurred as a result of the fire. The canvas trailer top was completely destroyed and the aluminum side panels were partially destroyed, causing an estimated loss of $\$ 1,200$. 


\section{CLASS I}

\section{CASE $n$}

Description of Operation

Truck shipment of container

Nature of Incident

Vehicular failure

Date: November 3, 1959

Type of Radioactive Material Involved

Not specified

Radiation Consequences of the Incident

None

Details of the Incident

A trailer of special design used for transporting deionizer casks failed just as the rig turned into an entrance from a main road.

The unit was operating at a very slow speed in order to negotiate the short radius at the location. While making the turn, the $3 \frac{3}{4}$ in. shaft that connects the right walking beam to the rear axle spindle broke at the point where the shaft enters the beam assembly. The sudden shift of weight created severe stress on the left walking beam, resulting in the breaking of the front spindle shaft at the corresponding point. The rig was stopped immediately without further incident.

Nature of Injuries or Loss

Loss to the trailer amounted to $\$ 1,300$. 


\section{CLASS I}

\section{CASE 12}

Description of Operation

Truck shipment of irradiated fuel elements

Nature of Incident

Vehicular failure

Date: April 15, 1960

Type of Radioactive Material Involved

Fission products

Radiation Consequences of the Incident

The cask remained intact and there was no contamination

Details of the Incident

Upon turning onto the highway, traveling at the rate of approximately five $\mathrm{mph}$, the trailer became unhitched from the tractor. As the front end of the trailer tilted and struck the ground, the cask containing the fuel elements (wt. 13,820 lb.) slid along the trailer floor and broke through the end of the trailer. There was no damage to the cask.

Nature of Injuries or Loss

In addition to the physical damage to the trailer, the shipment was delayed en route for a period of 24 hours and had to be reloaded on another trailer to complete its journey. A team was called to make a radiological survey, and two representatives of the receiver traveled to the accident scene to inspect the cask. No dollar loss was reported. 


\section{CLASS I}

\section{CASE 13}

Description of Operation

Truck shipment of source material

Nature of Incident

Vehicular failure

Date: November 15, 1960

Type of Radioactive Material Involved

Uranium hexafluoride

Radiation Consequences of the Incident

None

Details of the Incident

The tractor-trailer was proceeding up a slight grade when the trailer disengaged from the tractor, causing it to fall to the roadway.

Nature of Injuries or Loss

Shipment was delayed for several hours. Cost of retrieving equipment was $\$ 915$. 


\section{CLASS I}

\section{CASE 14}

Description of Operation

Truck shipment of cask

Nature of Incident

Tiedown failure

Date: July 26, 1960

Type of Radioactive Material Involved

Not specified

Radiation Consequences of Incident

None

Details of Incident

A 14-ton cask was being hauled onsite by truck. The driver of the vehicle halted for a stop sign. The chains used for tiedown devices snapped, and the cask slid from the bed of the truck.

Nature of Injuries or Loss

The cask was slightly damaged. Approximately $\$ 200$ was required for straightening and polishing the cask. 


\section{CLASS I}

\section{CASE 15}

Description of Operation

Rail shipment of special nuclear material

Nature of Incident

Derailment

Date: February 19, 1959

Type of Radioactive Material Involved

89,000 pounds of natural and slightly enriched uranium slugs packed in 45 wooden boxes

Radiation Consequences of Incident

None

Details of Incident

A freight car containing uranium slugs was being shipped by rail. The freight car in question had been standing, along with other cars, on a siding awaiting coupling to a westbound freight. Five cars moving on a parallel adjacent track were derailed and one of them fell over on the car containing the uranium shipment.

An AEC radiological assistance team inspected the shipment and monitored the car and surrounding area. There was negligible damage to the car and the shipment was intact. The car was resealed and shipped the following day.

Nature of Injuries or Loss

Delay of one day in shipment. 


\section{CLASS I}

\section{CASE 16}

Description of Operation

Rail shipment of source material

Nature of Incident

Derailment

Date: April 17, 1959

Type of Radioactive Material Involved

Boxed natural uranium bricks

Radiation Consequences of Incident

None

Details of Incident

Twenty-one cars of a 65-car freight train derailed. The shipment, in the thirty-third car of the train, remained upright, although the trucks were broken off. The shipment was transferred to another freight car before continuing to its destination.

Nature of Injuries or Loss

Shipment was delayed five days. A radiological assistance team was dispatched to check conditions of shipment. An AEC representative supervised transhipment. 


\section{CLASS I}

\section{CASE 17}

Description of Operation

Rail shipment of irradiated fuel elements

Nature of Incident

Derailment

Date: July 14, 1961

Type of Radioactive Material Involved

Fission products

Radiation Consequences of the Incident

No damage to cask car and no contamination or increase in radiation intensity at surface

Details of the Incident

Derailment of the cask car and the courier caboose occurred when the cars were entering the yard on a sharp curve, moving at a speed of 10-12 mph.

Nature of Injuries or Loss

No damage to cask car or caboose. Cars were re-railed and shipment continued. 


\section{CLASS I}

\section{CASE 18}

Description of Operation

Rail shipment

Nature of Incident

Impact

Date: October 31, 1959

Type of Radioactive Material Involved

Not specified

Radiation Consequences of the Incident

None

Details of the Incident

During a routine movement onsite of a train consisting of two railroad flatcars, one shielded cask car, and an electric locomotive, the locomotive operator attempted to stop the train, but due to malfunction of the brakes or improper setting of the brake switch, the train failed to stop until it hit the car stop.

Nature of Injuries or Loss

Damage to the cask car amounted to $\$ 1,500$. 


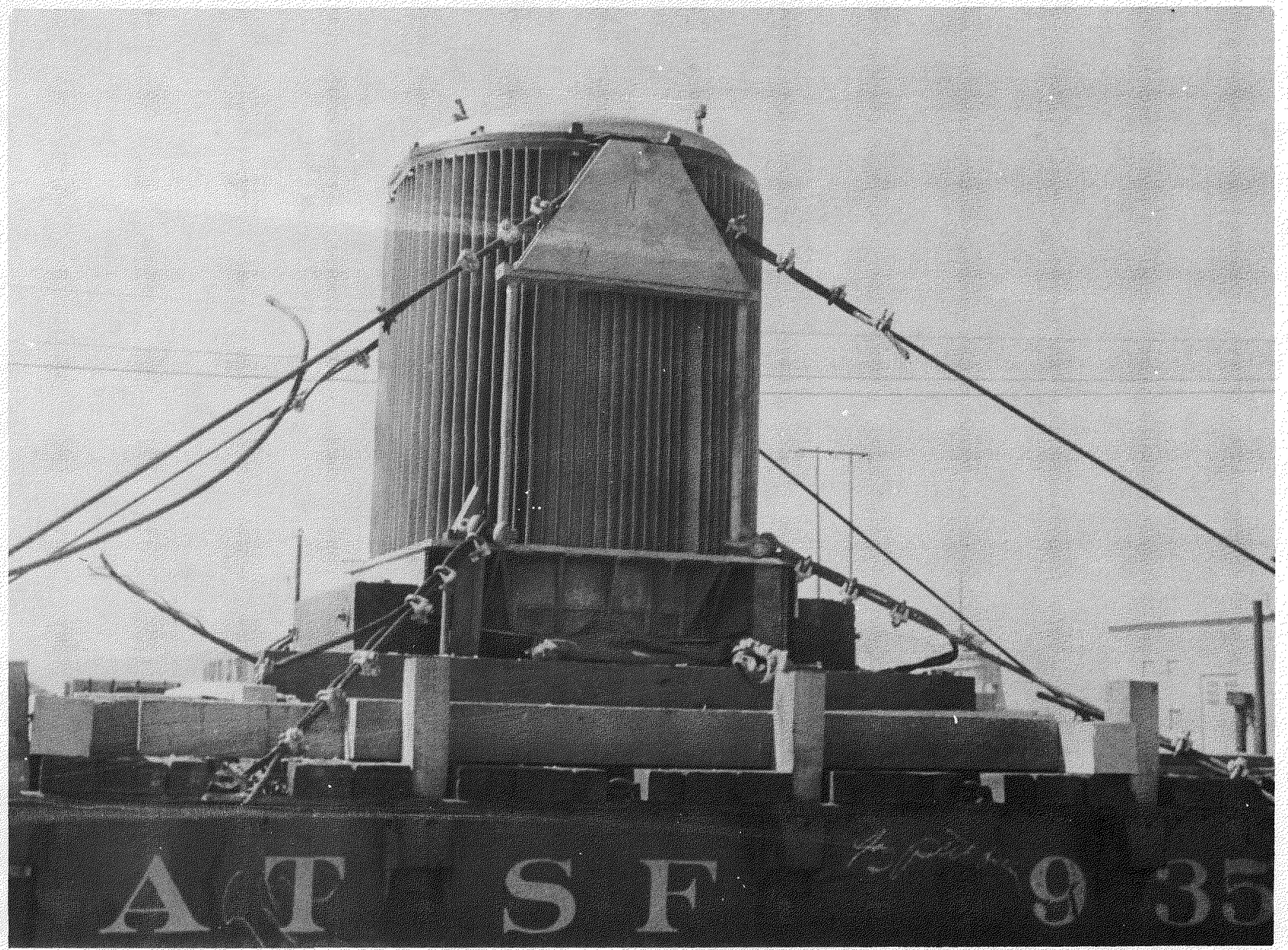

- 


\section{CLASS I}

CASE 19

Description of Operation

Rail shipment of irradiated fuel elements

Nature of Incident

Impact

Date: December 7, 1960

Type of Radioactive Material Involved

Fission products

Radiation Consequences of the Incident

None

Details of the Incident

A flatcar, loaded with a 25,500-lb. fuel element cask, was one of three cars standing in a rail siding at a freight yard. A switch engine backed into the cars with sufficient impact to jounce them approximately 300 feet down the track. The cask, secured with light $3 / 4$ in. cable ties and base cribbing, was not displaced; however, cable ties were stretched. Two couriers in the involved caboose were thrown from their beds.

Nature of Injuries or Loss

The couriers were badly shaken. They received medical attention, including X-ray examination, at the local hospital, and were released. No disabling injuries were experienced. Approximately 20 man-hours were expended to check out and investigate the accident. The third car, not involved in the shipment, suffered structural damage (extent undetermined). 


\section{CLASS I}

\section{CASE 20}

Description of Operation

Rail shipment of source materials

Nature of Incident

Fire

Date: May 6, 1958

Type of Radioactive Material Involved

Uranium oxide

Radiation Consequences of the Incident

None. The fire was extinguished before reaching the shipment.

Details of Incident

A journal box fire occurred on a flatcar in the railroad yards. The fire spread to the wooden platform of the car. Railroad employees attempted to extinguish the fire but could not. The local fire department was called and extinguished the fire, using $\mathrm{CO}_{2}$ and a booster (water) line.

Nature of Injuries or Loss

The wheels of the car had to be changed, and the shipment was delayed for approximately 48 hours.

Remarks

Hotbox fires are fairly common and can easily spread to the wooden platform of a car, as happened in this case. Exposure to shipments of radioactive materials and to structural members holding shipments in place could be reduced by replacing such platforms with suitable noncombustible material. It could be reduced to a lesser extent by insulating the underside of wooden platforms (over the journal boxes) with suitable noncombustible material to minimize the possibility of a hotbox fire spreading to the wooden platform. 


\section{CLASS I}

CASE 21

Description of Operation

Rail shipment of source material

Nature of Incident

Fire

Date: July 9, 1959

Type of Radioactive Material Involved

17955 -gallon steel drums containing uranium ore concentrate (oxides)

Radiation Consequences of the Incident

None. The drums of ore were unaffected by the flames of the fire.

Details of the Incident

A boxcar containing uranium ore concentrate packaged in 55-gallon drums developed a "hotbox," and was placed on a siding for cooling. Fire subsequently broke out in the hotbox and spread to the wood floor of the boxcar before firefighting activities were initiated and the fire controlled. None of the drums were damaged nor were any of the contents of the drums released. Repairs to the boxcar were conducted without removing any of the drums, following which the car proceeeded to its originally intended destination without incident.

Nature of Injuries or Loss

A small section of the boxcar floor was damaged by the fire and had to be repaired before the shipment could continue. 


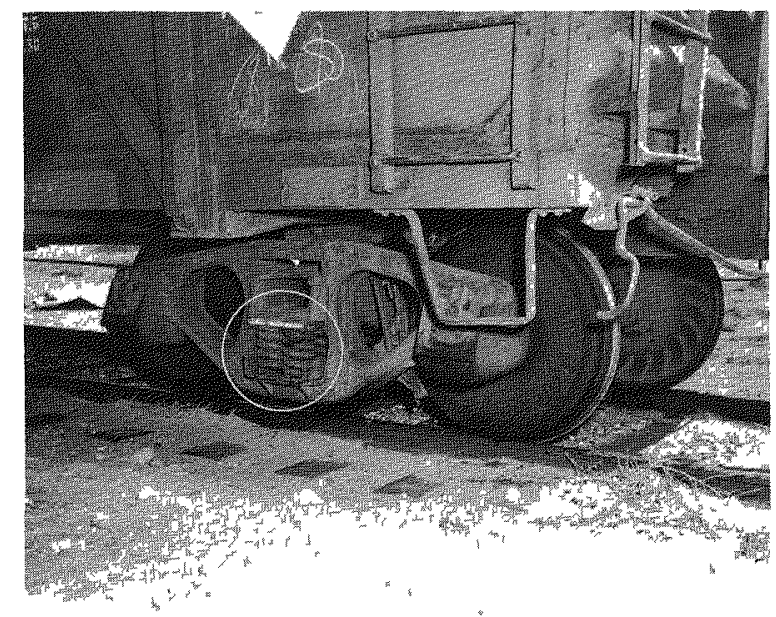

Replacement Springs and Jury-Rigged Spring Plank.

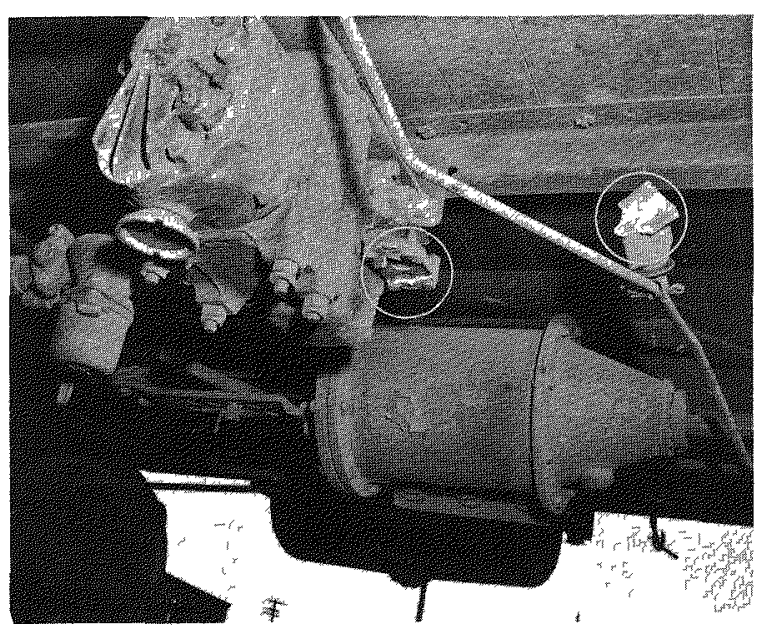

Shattered Air Fitting on Left Side of Courier Caboose.

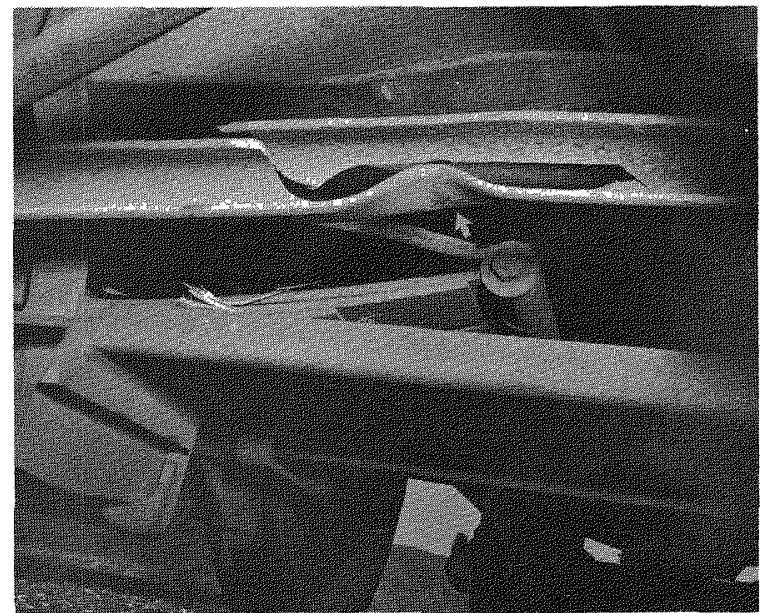

Damage to Undercarriage of Car Caused by Steel Debris.

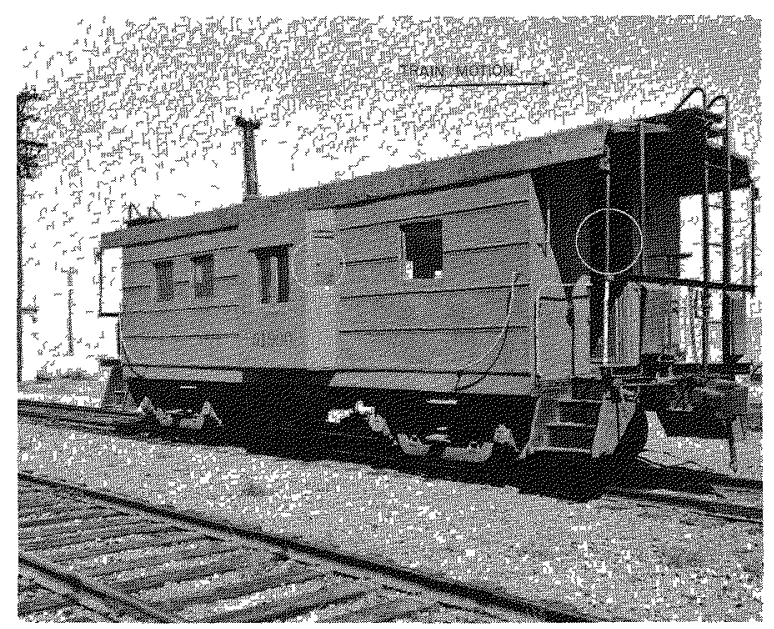

Broken Windows in Caboose Caused by Flying Stones. 


\section{CLASS I}

\section{CASE 22}

Description of Operation

Rail shipment of irradiated fuel elements

Nature of Incident

Equipment failure

Date: July 29-30, 1957

Type of Radioactive Material Involved

Fission products

Radiation Consequences of the Incident

None

Details of the Incident

A railroad shipment of irradiated rods was involved in two incidents which could have resulted in a serious accident. Fortunately, the shipment reached its destination without a derailment or wreck occurring.

The first such incident occurred when two cars twice uncoupled and separated from the train. This was repaired by securing the pins on the drawbar with baling wire and the shipment continued on its way.

The second incident occurred several hours later when the caboose, in which the escorts were riding, was struck by a shower of rocks, followed by a severe impact under the car. In the same commotion, the airhose of the caboose and another car were cut.

The crew repaired the airhose, but found nothing to indicate the cause of the trouble and the train proceeded.

Later, a stop was made to transfer three cars to another line. During this delay, the guards thoroughly inspected the remaining cars and discovered that a spring plank and several springs had broken. It was determined that the missing part of the plank cut the airhose. Twelve springs and the spring plank were replaced at this stop. The train proceeded to its destination.

Nature of Injuries or Loss

Damage to caboose had to be repaired before shipment could proceed. Shipment was delayed three times.

Remarks

These incidents indicate the need to ascertain that thorough inspections of railroad shipments involving radioactive material are made prior to movement and while the shipment is in transit. 


\section{CLASS I}

\section{CASE 23}

Description of Operation

Rail shipment of contaminated machinery

Nature of Incident

Leakage en route

Date: July 2, 1959

Type of Radioactive Material Involved

Not specified, probably uranium

Radiation Consequences of the Incident

None

Details of the Incident

A large piece of machinery labeled with radiation warning tags was being shipped. Railroad workers noted the leakage of some fluid from this piece of machinery. A radiological assistance team was dispatched. The survey revealed no contamination or external radiation. The leaking fluid also failed to reveal any radioactivity.

Close inspection revealed that the machinery was a refueling machine used in a reactor program. The fluid was probably sodium hydroxide formed as the result of a chemical reaction between decontamination washings and extraneous amounts of sodium from the cooling system. The refueling machine was en route for burial, and the radiation hazard tags had been placed on the machine because of the possibility of some internal contamination.

Nature of Injuries or Loss

Six hours delay in shipment. 


\section{CLASS I}

\section{CASE 24}

Description of Operation

Truck shipment of cask

Nature of Incident

Overturn of cask at truck terminal

Date: August 5, 1960

Type of Radioactive Material Involved

Not specified

Radiation Consequences of the Incident

None

Details of the Incident

The cask was accidentally tipped over at the terminal. The courier was concerned about a possible release of radioactive material and notified the shipper. The shipper, in turn, called an $A E C$ office located in the same city as the carrier's terminal. The AEC office sent out personnel who monitored the cask and found no release of radioactivity.

Nature of Injuries or Loss

No loss is reported. 


\section{CLASS I}

\section{CASE 25}

Description of Operation

Rail shipment of radioisotopes

Nature of Incident

Overturn of container in rail terminal

Date: October 19, 1959

Type of Radioactive Material Involved

150 curies of iridium-192

Radiation Consequences of the Incident

None

Details of the incident

A cask containing 150 curies of Ir -192 being shipped by rail was overturned at a loading dock in a large mid-western city. The railroad employees noticed that some liquid had spilled from the cask. The Army was called to monitor the cask but found no apparent contamination. The AEC was then called and a radiological assistance team dispatched. The team found a maximum external radiation level in the order of $6 \mathrm{mr} / \mathrm{hr}$ as was posted on the container, and verified the lack of contamination. The water that spilled was evidently some rain water that collected on the top of the cask. The cask was then released for shipment.

Nature of Injuries or Loss

None 


\section{CLASS I}

\section{CASE 26}

Description of Operation

Rail shipment of radioisotopes

Nature of Incident

Overturn of container in rail terminal

Date: June 4, 1961

Type of Radioactive Material Involved

34-curie polonium-beryllium neutron source

Radiation Consequences of the Incident

None

Details of the Incident

A 70-gallon paraffin-lined drum, containing a 34-curie polonium-beryllium neutron source which was being shipped by rail, was found leaking in a railway express depot. The radiological assistance team investigated and found no contamination. The container was properly marked. A sample of the liquid which had leaked from the drum was analyzed but no activity found.

Nature of Injuries or Loss

None 


\section{CLASS I}

\section{CASE 27}

Description of Operation

Railway express shipment of radioisotopes

Nature of Incident

Overturn of container in REA depot

Date: May 27, 1961

Type of Radioactive Material Involved

7-curie plutonium-beryllium neutron source

Radiation Consequences of the Incident

None

Details of the Incident

The railway express depot reported to the police department that a drum containing $\mathrm{Pu}-239$ had been tipped over in their station and some liquid had been spilled. The police called the AEC and a radiological assistance team was dispatched.

The source was being shipped in a 30-gallon paraffin-lined drum. As the drum was being moved across the station on a hand car, the two employees tipped the drum on its side and noticed a liquid leaking out.

No contamination was found on or near the drum or on the workers. The liquid was evidently either rain water or condensation.

Nature of Injuries or Loss

None 


\section{CLASS I}

\section{CASE 28}

Description of Operation

Air freight shipment of radioisotopes

Nature of Incident

Leakage at air terminal

Date: June 23, 1960

Type of Radioactive Material Involved

The shipment contained 10 pellets of iridium-192, each ranging between 16.7 and 23.5 curies, for a total of 200.8 curies.

Radiation Consequences of the Incident

None. Survey revealed all readings to be within tolerances.

Details of the Incident

A shipment of Ir-192 was reported leaking at an airport. Investigation revealed no contamination of the shipping container and that instrument readings were within the shipping limits prescribed $(20 \mathrm{mr} / \mathrm{hr}$ at surface and 1 to $1.1 \mathrm{mr} / \mathrm{hr}$ at 1 meter $)$. There was no evidence of any damage to the container which was padlocked and sealed.

It was presumed that the reported leakage resulted from external water which was absorbed by the gasket seal or seeped into the container during exposure to rain or hosing.

Nature of Injuries or Loss

No delay of shipment resulted. A survey team was required and approximately two manhours were expended to determine that there was no leakage. 


\section{CLASS I}

\section{CASE 29}

Description of Operation

Air freight shipment

Nature of Incident

Dropped container at air terminal

Date: November 15, 1960

Type of Radioactive Material Involved

Not specified

Radiation Consequences of the Incident

None

Details of the Incident

A shipment of radioactive material was dropped as it was being unloaded from a plane. The airline called the local AEC office for assistance. AEC representatives surveyed the package and could find no damage or release of radioactive material.

Nature of Injuries or Loss

No loss is reported. AEC representatives were called out to inspect the shipment. 


\section{CLASS \|I RADIATION RELEASE}

The package integrity is breached. However, there is no release of radioactive materials. 


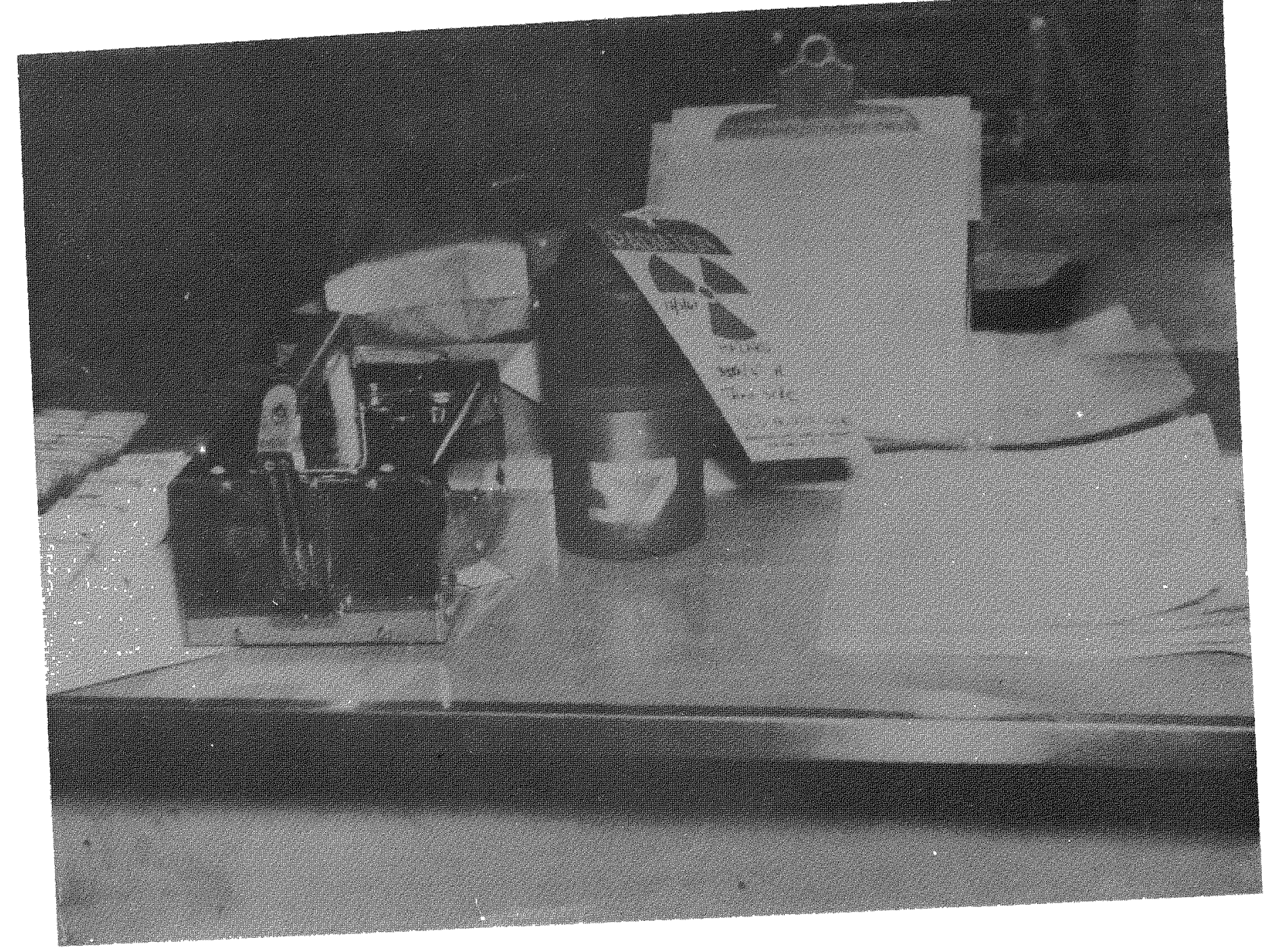

The Inner Container as Found, After Being

The Inner Contiological Assistance Team.

0. 


\section{CLASS II}

\section{CASE 1}

\section{Description of Operation}

Truck shipment of radioisotopes

Nature of Incident

Impact and overturn

Date: December 7, 1961

Type of Radioactive Material Involved

The material consisted of wires containing approximately five curies of cobalt- 60

Radiation Consequences of the Incident

No radioactive material was released. The inner container remained intact; however, the radiation level at the surface was found to be $350 \mathrm{mr} / \mathrm{hr}$ rather than $200 \mathrm{mr} / \mathrm{hr}$ as specified by the ICC Regulations.

\section{Details of the Incident}

A shipment consisting of one container of radioactive cobalt dosimeters was being shipped by commercial truck. The radioactive material was contained in a cylindrical lead cask about 3 in. in diameter and $9 \mathrm{in}$. high with a bolted-on lid. This cask was packaged in a cardboard outer container about 24 in. cubed. The outer container was labeled indicating the radioactivity to be 0.05 units. The truck was involved in an accident, overturning, causing the lead cylinder to be ejected from its outer cardboard container. The lead cylinder was unmarked but was found intact. Two long bolts passing through the container from the bottom held the top on the container and there were no signs of the bolts having been removed or replaced since the original sealing of the container. The top was securely fastened.

A survey of the container revealed radiation intensities up to $350 \mathrm{mr} / \mathrm{hr}$ at $2 \mathrm{in}$. Smear surveys revealed no surface contamination of the container; the trailer likewise showed no signs of contamination.

Nature of Injuries or Loss

The shipment was repackaged in a wooden box. The three members of the radiological assistance team spent two hours on the incident.

Remarks

This case indicates the need for labeling inner containers to provide proper identification where such containers may become separated from the package. 


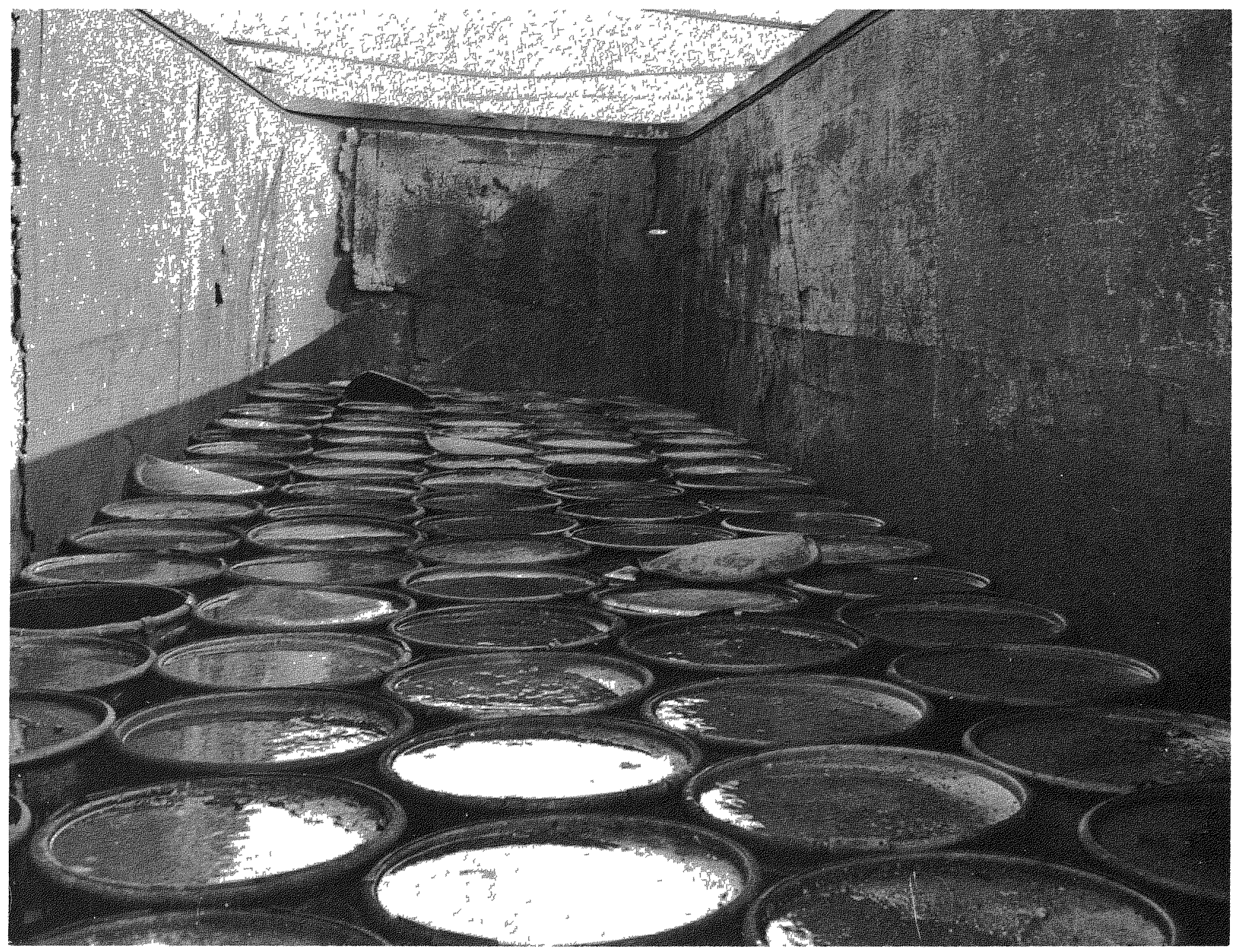

- 


\section{CLASS ॥}

\section{CASE 2}

Description of Operation

Truck shipment of source materials

Nature of Incident

Fire

Date: April 22, 1961

Type of Radioactive Material Involved

The material consisted of normal uranium (metal) chips in oil

Radiation Consequence of the Incident

No radioactive material was released from the containers.

\section{Details of the Incident}

A semitrailer containing drums of uranium chips (metallic) was parked at an unloading site on Friday noon to be unloaded on the following Monday morning. During a routine inspection by a plant guard in the early evening, the trailer was found to be secure. On repassing the trailer two to three minutes later, the guard noted that the trailer had burst into flames. The blaze was extinguished by the plant fire brigade.

Examination of the drums of uranium chips after the fire was extinguished revealed that lids were off several drums, almost as if by explosion (this has not been established as fact). A radiological check of the immediate area revealed no apparent spread of contamination due to the fire.

The fire spread to a Government trailer parked next to the commercial trailer and caused minor damage to the Government vehicle.

Nature of Injuries or Loss

The extent of damage to the trailer (privately owned) included destruction of interior body paneling, four tires, tarpaulin, one-third of the flooring, and brake and light systems. Dollar value $\$ 1,500$.

The Government trailer suffered minor damage to floor and one tire, and one tarpaulin was destroyed. Dollar value $\$ 500$.

Although there was no loss of uranium, there was a reduction in value of the uranium due to oxidation of the metallic chips. Dollar value (est.) $\$ 3,000$. Total loss $\$ 5,000$. 
- 


\section{CLASS II}

\section{CASE 3}

Description of Operation

Truck shipment of source material

Nature of Incident

Arrival of breached container

Date: April 12, 1957

Type of Radioactive Material Involved

Normal metal uranium slugs

Radiation Consequences of the Incident

None

Details of the Incident

Upon arrival at destination, one box of material was noted to be broken open and one piece of planking, approximately $2 \times 8$ in. was missing. The box was removed from the truck and weighed. Gross weight proved to be correct.

Nature of Injuries or Loss

None 


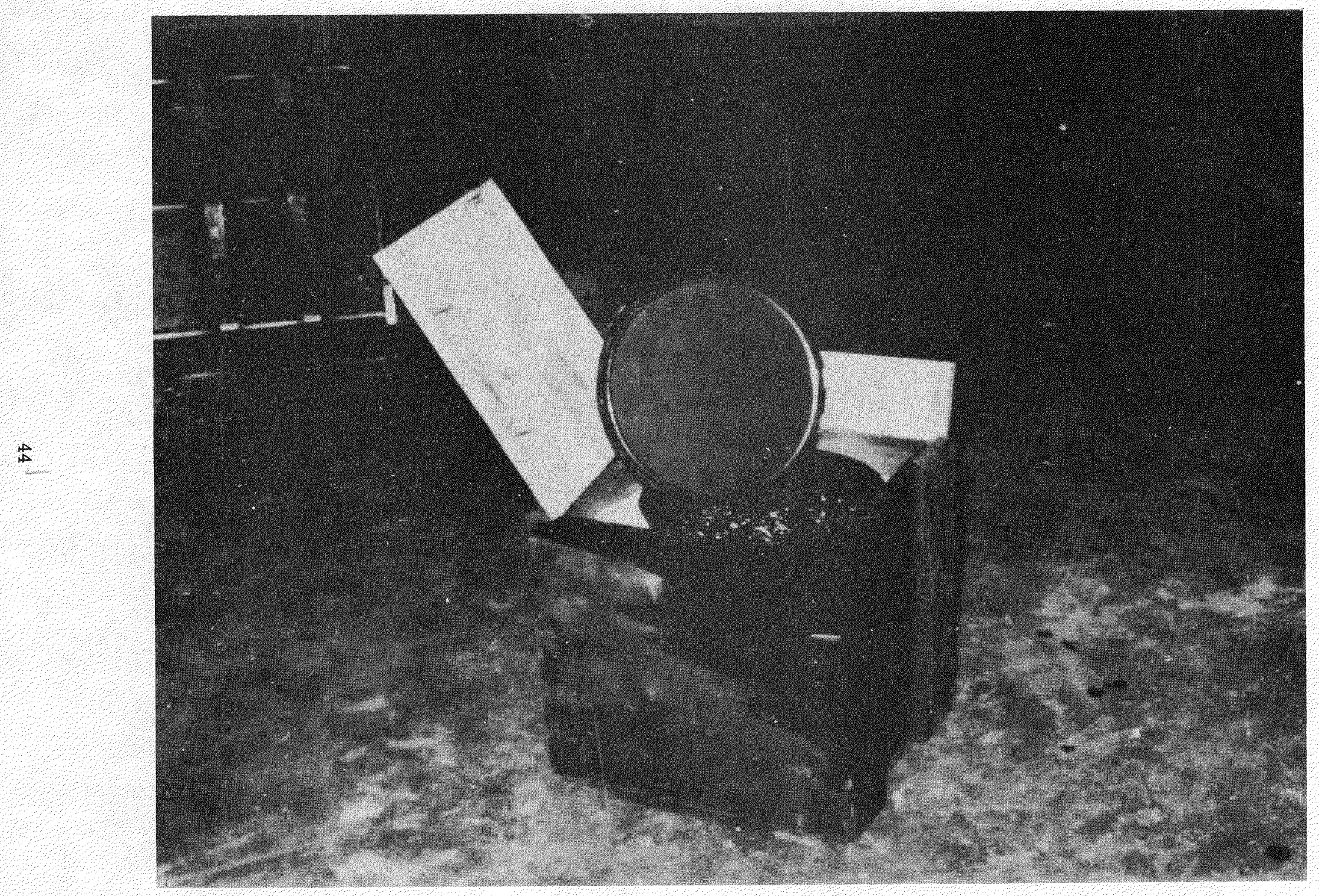

- 


\section{CLASS II}

\section{CASE 4}

Description of Operation

Truck shipment of source material

Nature of Incident

Leakage in truck terminal

Date: May 20, 1959

Type of Radioactive Material Involved

Normal uranium turnings in oil

Radiation Consequences of the Incident

None

Details of the Incident

A trailer loaded with drums of U-turnings in oil parked at a truck terminal developed an oil leak in the drums. The shipper was notified and subsequently dispatched a truck and necessary personnel to the terminal to transfer the entire load and return to origin. The entire area at the terminal was monitored, and no contamination was found.

Nature of Injuries or Loss

Shipment was delayed for several days. A team was required to monitor the truck terminal, the entire shipment had to be inspected and the faulty drums had to be repaired or replaced before the shipment should proceed. 


\section{CLASS II}

\section{CASE 5}

Description of Operation

Air shipment of radioisotopes

Nature of Incident

Package run over by truck at terminal

Date: July 7, 1959

Type of Radioactive Material Involved

850 microcuries of iodine-131

Radiation Consequences of the Incident

None

Details of the Incident

A package containing 10 gelatin capsules containing 850 microcuries of I- 131 was dropped during transfer at an airport and run over by a truck. A radiological assistance team representative found no contamination and the package was turned over to the radiological assistance safety officer at a nearby university who found the capsules intact. The capsules were repacked and shipped to their destination.

Nature of Injuries or Loss

None 


\section{CLASS \|}

\section{CASE 6}

Description of Operation

Air shipment of radioisotopes

Nature of Incident

Container fell from truck at terminal

Date: September 2, 1959

Type of Radioactive Material Involved

10 sodium iodide capsules containing 380 microcuries of iodine- 131

Radiation Consequences of the Incident

None

Details of the Incident

In the process of transferring the package of material from one air freight firm to another via truck, the package dropped off the truck and had evidently been struck by a vehicle of some sort. The damaged package was found by a third party and the capsules found intact. The package was resealed and because of the radioactivity sign attached, the AEC radiological assistance team was called. The team surveyed the package and found no contamination on or in the package.

Nature of Injuries or Loss

None 


\section{CLASS II}

\section{CASE 7}

Description of Operation

Air shipment of radioisotopes

Nature of Incident

Container run over by airplane

Date: July 25, 1961

Type of Radioactive Material Involved

118 millicuries of calcium -45

Radiation Consequences of the Incident

None

Details of the Incident

The package containing the Ca-45 was damaged at an air terminal when it was run over by an airplane. Firemen at the airport transferred the package to a local hospital where personnel inspected the package and found the inner container to be intact and that no leakage had occurred. A new outer package was sent to the hospital where the shipment was repackaged and returned to the air terminal.

Nature of Injuries or Loss

The shipment was delayed for 24 hours. 


\section{CLASS III RADIATION RELEASE}

Radioactive material is released, but is confined to the package or the vehicle. 


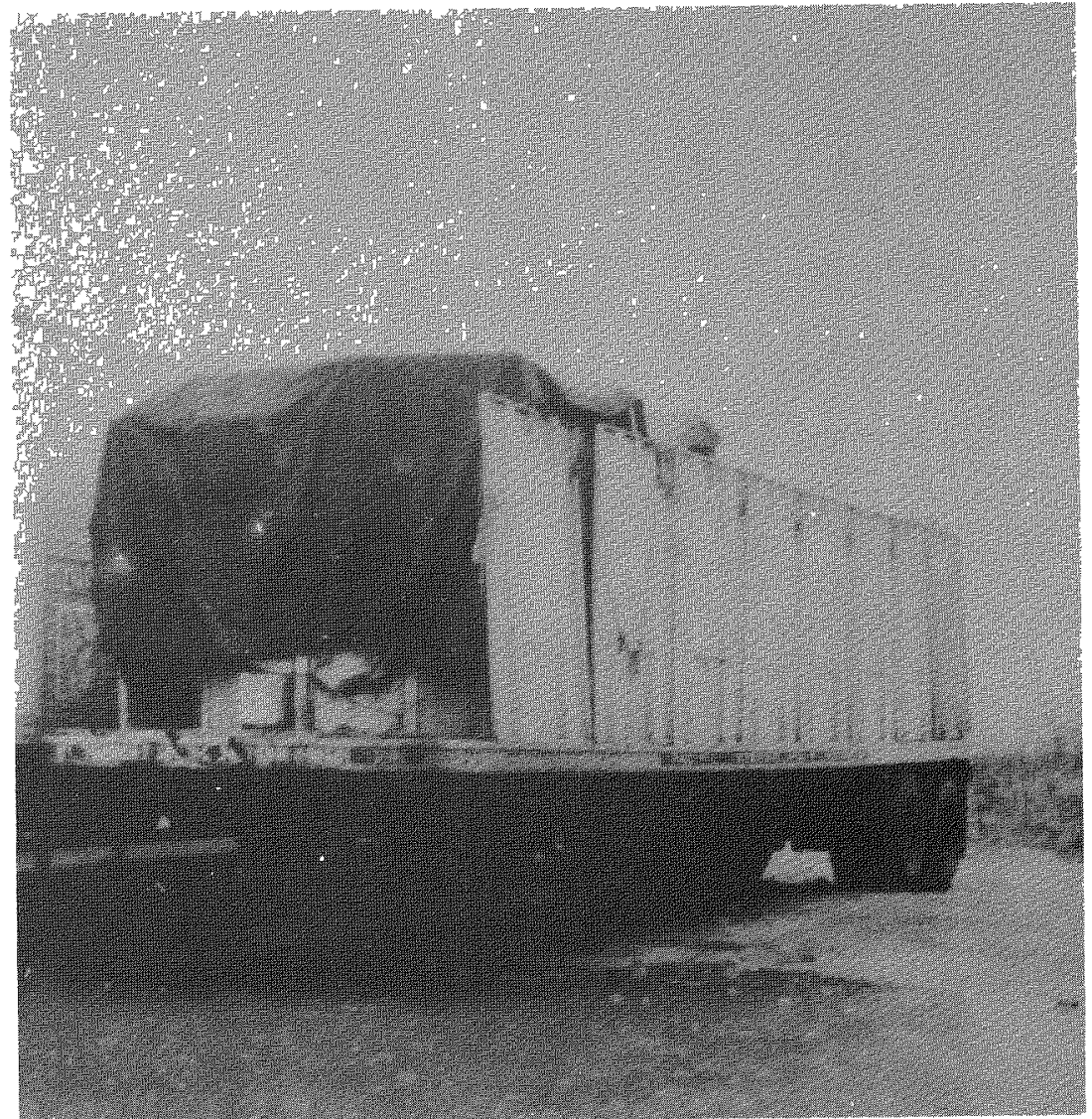

Front View of Trailer After Incident.

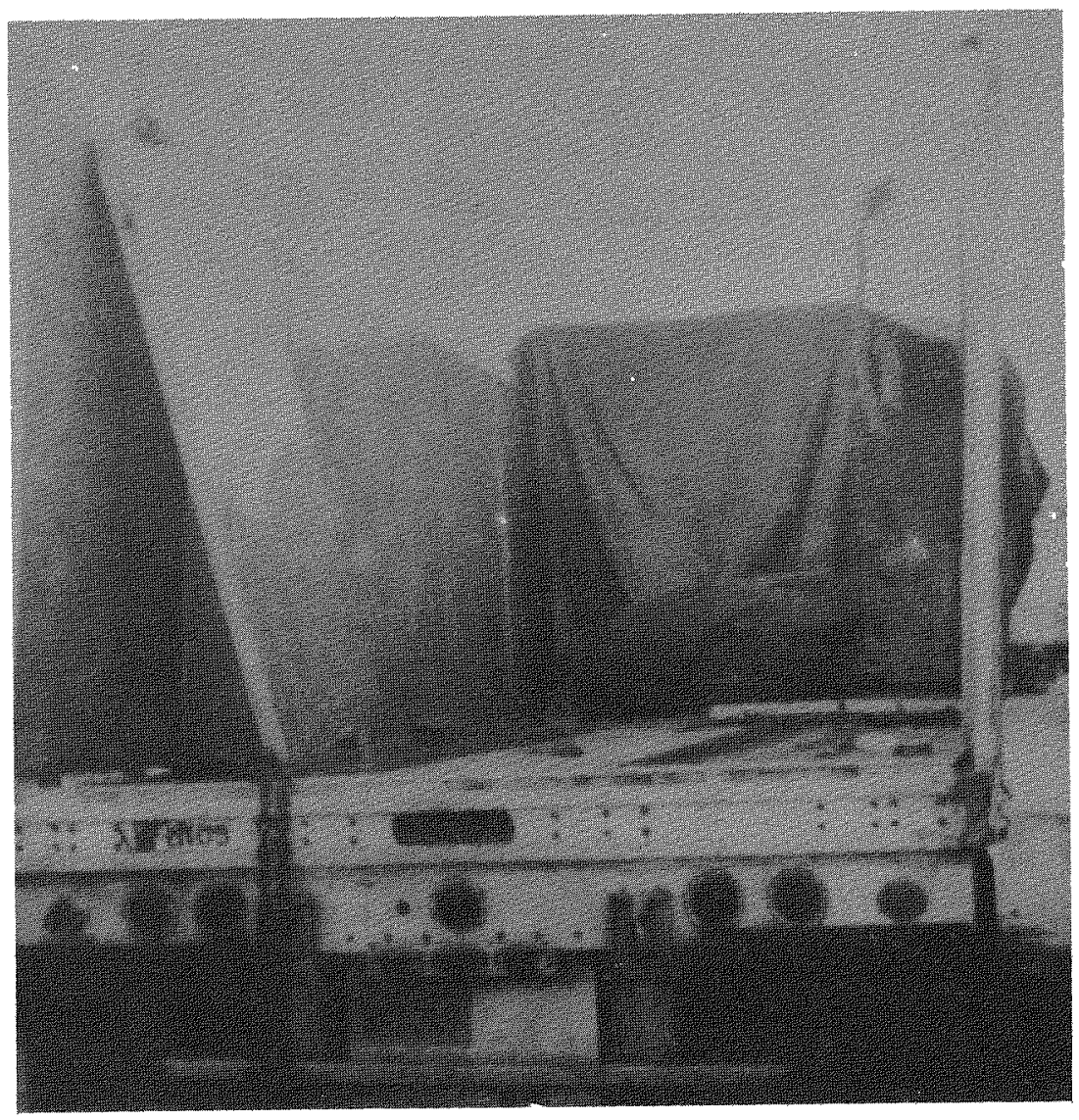

Rear View of Trailer After Incident. 


\section{CLASS III}

\section{CASE 1}

Description of Operation

Truck shipment of irradiated fuel elements

Nature of Incident

Impact; improper practices

Date: November 20, 1960

Type of Radioactive Material Involved

Irradiated fuel specimens in 19-ton shipping cask

Radiation Consequences of the Incident

The second trailer, onto which the cask was loaded, was found to be contaminated to approximately $250 \mathrm{mrep} / \mathrm{hr}$ and had to be decontaminated.

Details of the Incident

On arrival at a state port of entry, the patrolman on duty refused to let the truck proceed because the truck was carrying too much weight on the rear axle. After deliberation, it was decided that by relaxing the rear retaining chains of the cask, moving the truck forward and applying the brakes suddenly, the cask could be moved forward three or four inches. After three or four attempts, sufficient forward movement was obtained to satisfy the state's weight requirements. The tiedowns were resecured and the shipment proceeded without further incident to a large city in another state.

Here it was again decided to shift the load in order to meet the weight limitations of yet another state. Using the same technique as described above, the driver was unsuccessful in shifting the load on level terrain. He, therefore, drove to a downgrade where he applied the brakes at a speed of $15-18 \mathrm{mph}$. The cask moved forward very rapidly approximately 15 feet, tearing out the front of the trailer and bending the back of the sleeper compartment on the tractor. The chains holding the cask did not break, but the $1 / 2$ in. tiedown pins were pulled through the trailer deck. (Inspection prior to departure had revealed that tiedown pins were weld-anchored to the vertical facing on the inside of the outer channel forming the chassis of the trailer.)

Immediately following the incident, a radiation survey on the cask was made and no increase in radiation or evidence of contamination was detected nor was there any evidence of physical damage to the cask.

At the next terminal, the trailer was declared unroadworthy and the cask had to be transferred to another trailer. On this second leg of the shipment, the couriers noted a small liquid leak from below the cask resulting in a small damp spot on the trailer floor.

At destination, the bed of the trailer was found to be contaminated up to $250 \mathrm{mrep} / \mathrm{hr}$. After unloading, the trailer had to be decontaminated. A radiological assistance team assisted the carrier in his decontamination operations, which consisted of washing the bed and sides of the trailer and replacing several sections of the wooden floor. 
One of the couriers received a broken foot as a result of staying inside the trailer during the shifting operation. The original trailer was declared unroadworthy because the weight of the cask had bent the frame and it had to be repaired. The tractor sleeping compartment was damaged and had to be repaired. A second tractor-trailer had to be utilized to complete the shipment, and the trailer was found to be contaminated at destination. Several spots on the floor could not be decontaminated, and parts of the wood flooring had to be replaced. The decontamination was carried out under the supervision of the radiological assistance team.

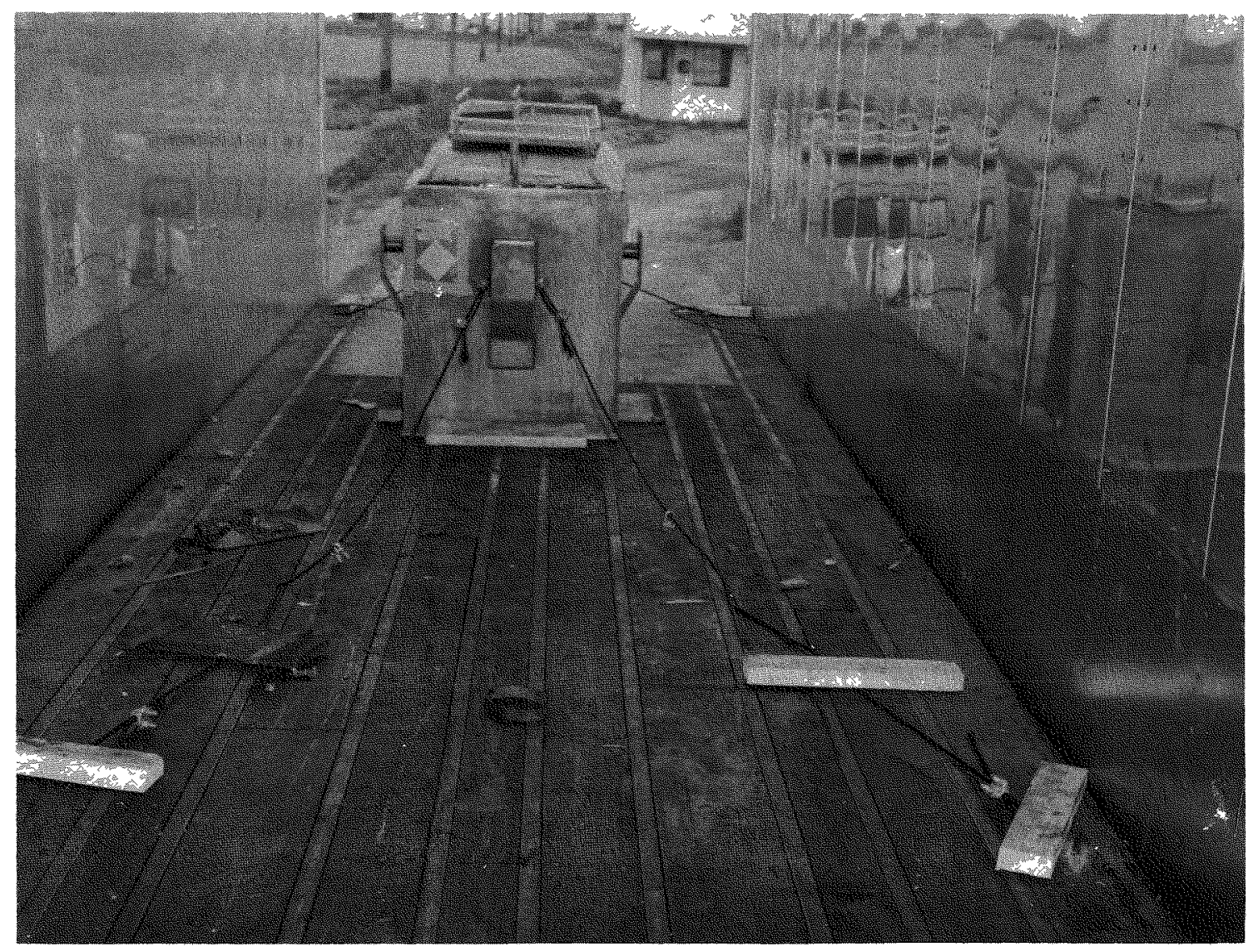

Photo for Class III Case 2 (See Facing Page). 


\section{CASE 2}

Description of Operation

Truck shipment of irradiated fuel elements

Nature of Incident

Tiedown failure

Date: September 22, 1961

Type of Radioactive Material Involved

Approximately 30,000 curies of fission products

\section{Radiation Consequences of the Incident}

The cask lid was contaminated to approximately $48,000 \mathrm{c} / \mathrm{m} / 100 \mathrm{~cm}^{2}$, beta-gamma. Contaminated areas totaling an estimated $15 \mathrm{sq} \mathrm{ft}$ were found on the trailer bed. Dose rates from the trailer bed ranged from $20 \mathrm{mrad} / \mathrm{hr}$ at $1 \mathrm{ft}$ to a maximum of $125 \mathrm{mrad} / \mathrm{hr}$ at $4 \mathrm{in}$.

\section{Details of the Incident}

The shipment contained approximately 30,000 curies of fission products in fuel elements carried in a 14,000-1b. container. The container was carried in a sealed, exclusive-use trailer. The tiedown arrangement consisted of cables from the cask attached to $2 \times 4 \mathrm{in}$. wood blocks nailed to the floor. En route from origin to destination, the trailer was hauled by three separate tractors. However, since the trailer was sealed, no one inspected the interior along its route.

At destination, it was discovered that the wood blocks had pulled loose and the container had shifted in transit. Apparently, residual water in the cask had splashed out during transit while the cask was shifting about and was the source of contamination.

Nature of Injuries or Loss

In order to decontaminate the trailer, some of the wood flooring was stripped off leaving readings of $0.4 \mathrm{mrad} / \mathrm{hr}$. At one point, a small hole was cut completely through the floor of the trailer where it appeared that liquid had entered a crack. Dollar value of the loss was not reported. 


\section{CLASS III}

\section{CASE 3}

Description of Operation

Package of contaminated equipment being transported onsite in AEC pickup truck

Nature of Incident

Leakage from rain-soaked package

Date: June 22, 1959

Type of Radioactive Material Involved

Type of material not reported

Radiation Consequences of the Incident

The chassis and bed of the pickup truck became contaminated.

Details of the Incident

Some contaminated equipment was packaged and monitored and then placed in the Government-owned pickup truck for onsite transport the following day. A rainstorm during the night submerged the package in water, and the package was, in turn, penetrated by the water. During transport of the package the following day, the water leaked from the package, contaminating the truck bed and chassis.

Nature of Injuries or Loss

The truck bed was replaced and the chassis of the vehicle was decontaminated by sandblasting. Cost of decontamination of the vehicle was $\$ 225$. 


\section{CLASS III}

\section{CASE 4}

Description of Operation

Truck shipment of empty container

Nature of Incident

Truck found to be contaminated at destination

Date: July 21, 1959

Type of Radioactive Material Involved

Not reported

Radiation Consequences of the Incident

Lower outside surface of container and pallet found to be contaminated to approximately $20 \mathrm{mr} / \mathrm{hr}$. Floor surface of trailer found to be contaminated up to $10 \mathrm{mr} / \mathrm{hr}$. Another trailer used in the earlier phases of the shipment of this cask was also surveyed and found to be contaminated up to $3 \mathrm{mr} / \mathrm{hr}$ in small sections.

Details of the Incident

An empty cask being transported by public carrier arrived at an AEC site contaminated. No other details reported.

Nature of Injuries or Loss

Decontamination of trailer was accomplished with expenditure of approximately 15 manhours. Trailer used in initial portion of transport decontaminated with approximately 10 manhours of work. Surveys of all terminals servicing this shipment had to be accomplished; however, no other contamination was detected. 


\section{CLASS III}

\section{CASE 5}

Description of Operation

Truck shipment of radioisotopes

Nature of Incident

Container dropped at truck terminal

Date: June 15, 1961

Type of Radioactive Material Involved

178.7 curies of thorium and 17.7 curies of ionium in 11 capsules contained in a steeljacketed lead-filled shipping container, wt. $3800 \mathrm{lbs}$. The container was filled with water for cooling purposes.

\section{Radiation Consequences of the Incident}

Liquid spillage from the overturned cask covered an area of about two to three square feet of the local delivery van, which turned to a grayish residue upon drying. Also contaminated were 12 pieces of channel iron and a box of hardware which were loaded on the van. Survey of the area revealed:

$$
\begin{array}{r}
4,000 \mathrm{c} / \mathrm{m} / 100 \mathrm{~cm}^{2} \text { beta-gamma on cask } \\
20,000 \mathrm{c} / \mathrm{m} / 100 \mathrm{~cm}^{2} \text { beta-gamma on spill } \\
3,800 \mathrm{~d} / \mathrm{m} / 100 \mathrm{~cm}^{2} \text { alpha on spill }
\end{array}
$$

Details of the Incident

A cask of radioactive material was being transferred from a long-haul van by forklift truck into the rear of a local delivery truck for movement to a connecting carrier's depot. The cask rolled off the forks of the lift and settled on its side, where liquid was observed running out of the top of the cask onto the floor of the truck. The liquid covered a three-sq-ft area and left a grayish residue when it dried. Radiation readings of the magnitude of 400 to $5,000 \mathrm{~d} / \mathrm{m} / 100 \mathrm{~cm}^{2}$ alpha and 2,000 to $3,000 \mathrm{c} / \mathrm{m} / 100 \mathrm{~cm}^{2}$ beta-gamma were observed at this spot.

After the incident, the truck and contaminated goods were dispatched for decontamination and the cask was dispatched in a trailer as a single-load, through-shipment to its destination.

Nature of Injuries or Loss

Four members of a radiological assistance team were involved for one day, the use of the truck (to its owner) was denied for one day, and one man-hour was required for cleanup of the vehicle and the contaminated goods. The final leg of the trip was made by exclusiveuse truck. No dollar value was assigned to the loss. 


\section{CLASS III}

\section{CASE 6}

Description of Operation

Rail shipment of radioactive waste

Nature of Incident

Leakage in rail terminal

Date: September 24, 1958

Type of Radioactive Material Involved slurry

Contaminated laundry, combustible dry waste, and two shielded drums of scrap uranium

Radiation Consequences of the Incident

Water underneath car read 160 to $180 \mathrm{cpm}$ on survey meter when car was removed. This is negligible.

Details of the Incident

A shipment of radioactive material was found leaking in a railroad terminal. A preliminary survey by railroad officials indicated $80 \mathrm{mr} / \mathrm{hr}$ near the car and $8 \mathrm{mr} / \mathrm{hr}$ near the water underneath the car. The railroad cars were isolated and roped off. A team was dispatched to monitor the shipment and take water samples. The exterior readings were verified but the water showed very slight activity. Further investigation indicated that the water had evidently come from a 55 -gallon drum, containing laundry water, which had a loose gasket.

Nature of Injuries or Loss

Shipment was delayed for two days while new gaskets were installed on the leaking drum. 


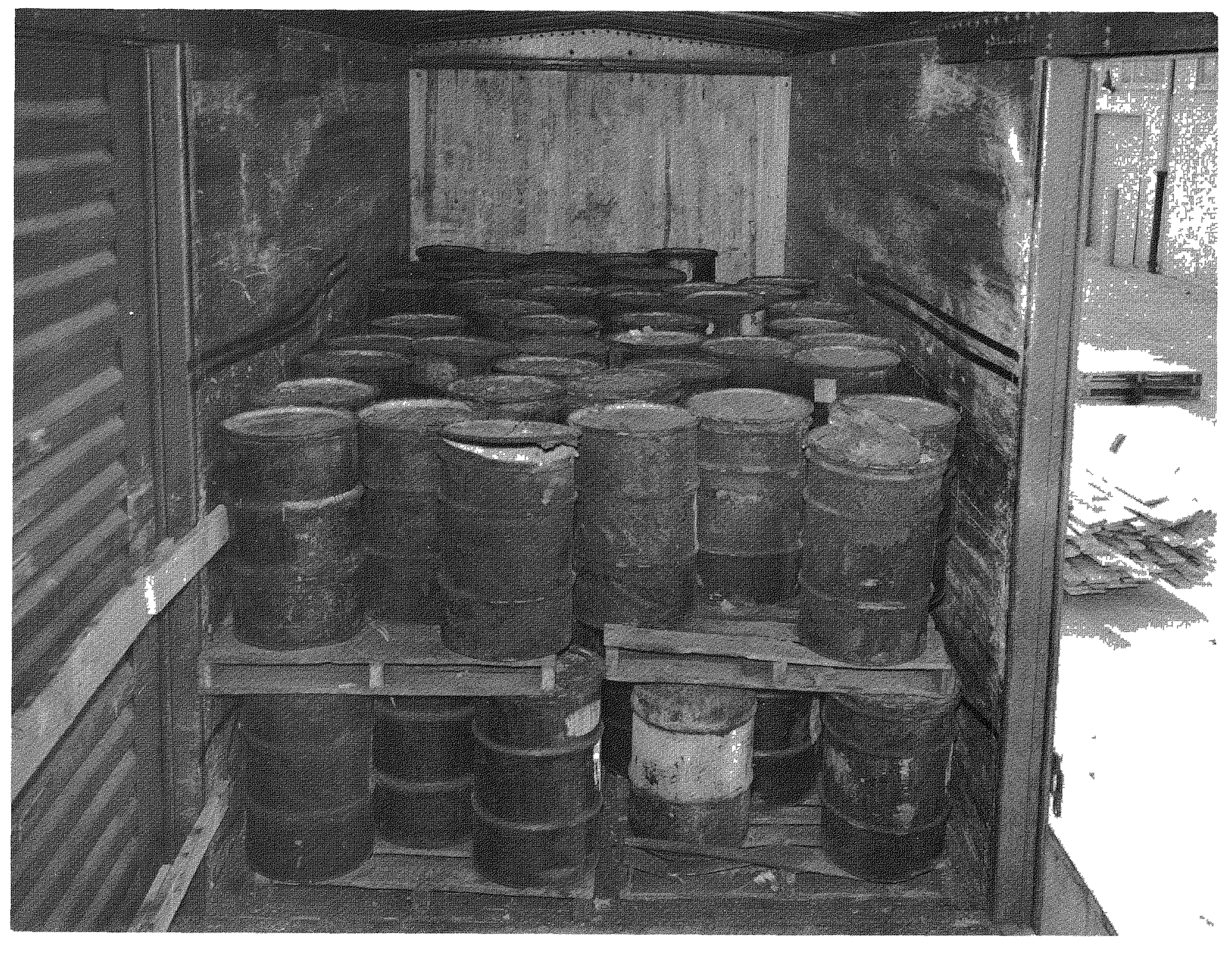

- 


\section{CLASS III}

\section{CASE 7}

Description of Operation

Rail shipment of radioactive waste

Nature of Incident

Leakage discovered at destination

Date: May 15, 1959

Type of Radioactive Material Involved

Contaminated residues in drums

Radiation Consequences of the Incident

None

Details of the Incident

A carload of contaminated residues contained in 55-gallon drums arrived at destination and, upon inspection, was found to be leaking. The car was unloaded and spillage was removed from the car floor and walls. After cleanup of the spillage, the floor and walls of the car were found to be highly contaminated. Complete decontamination required removal of floor and parts of wall.

Nature of Injuries or Loss

No personnel injuries. Loss amounted to cost of replacing floor and walls of car. 
- 


\section{CLASS IV RADIATION RELEASE}

Radioactive material is released to the ground or trafficway with no runoff or aerial dispersal. 


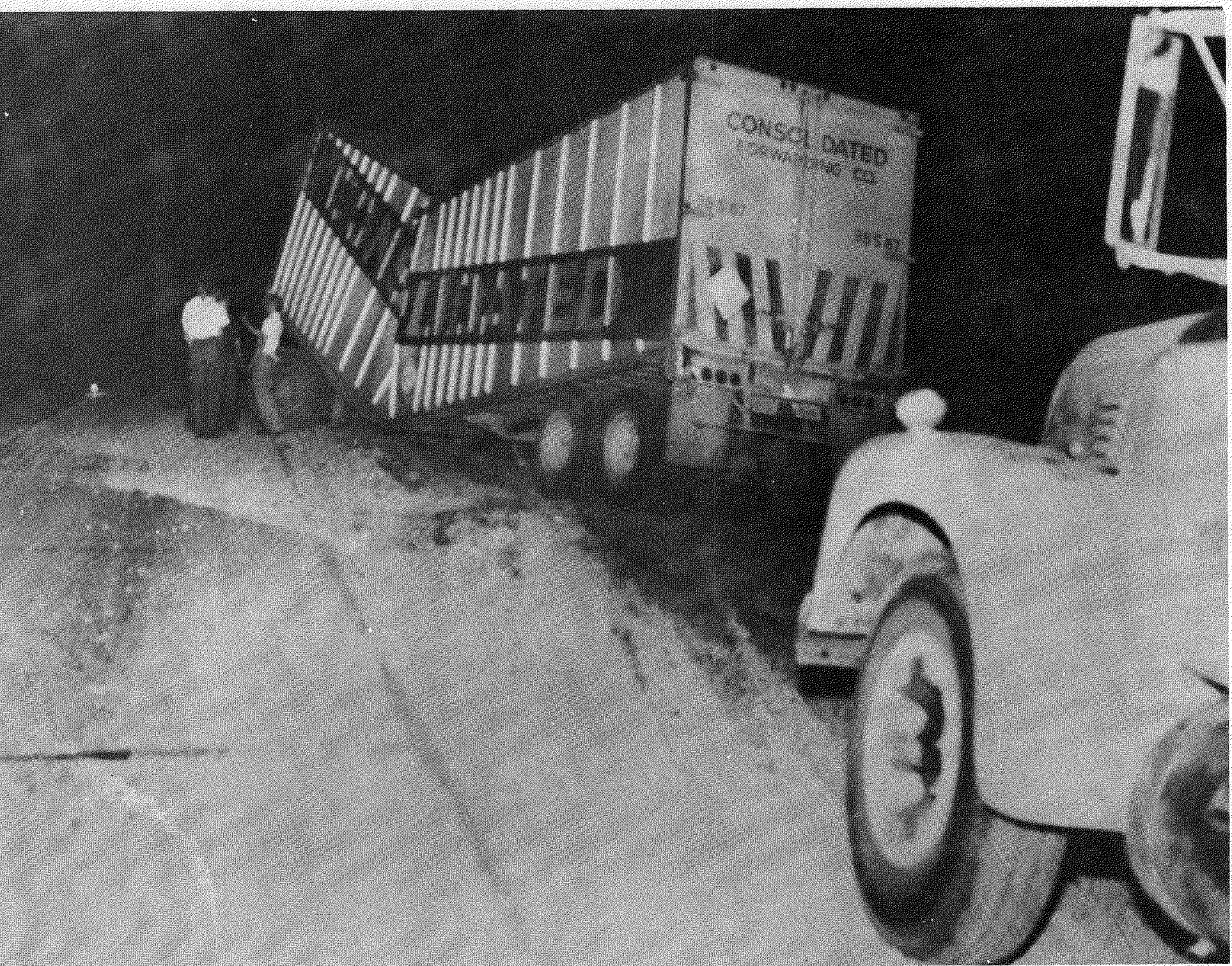

- 


\section{CLASS IV}

\section{CASE 1}

Description of Operation

Truck shipment of source material

Nature of Incident

Vehicular failure

Date: July 1, 1961

Type of Radioactive Material Involved

Approximately 37,000 pounds of normal uranium

Radiation Consequences of the Incident

The uranium bars had been packaged in wooden boxes which broke open spilling the material onto the highway. The bars were picked up and repackaged. There was no contamination.

Details of the Incident

A trailer carrying 24 boxes of normal uranium slugs collapsed and the tractor-trailer jackknifed into a ditch. Twelve boxes of slugs were thrown on the road, five boxes broke open, and slugs were scattered on both sides of the road.

No one was injured, and it was determined that there was no health hazard present.

The trailer collapsed due to structural failure, though the load was within the rated weight limits. It is possible that the highly concentrated load may have caused excessive stresses in some structural members, even though the total weight did not exceed the vehicle or road weight limits. Also, metal fatigue cannot be ruled out as a factor.

Nature of Injuries or Loss

Damage to the vehicle was estimated at $\$ 4,000$. No material was lost and no contamination occurred. Members of the state police, state health department, and AEC responded to the accident scene. 


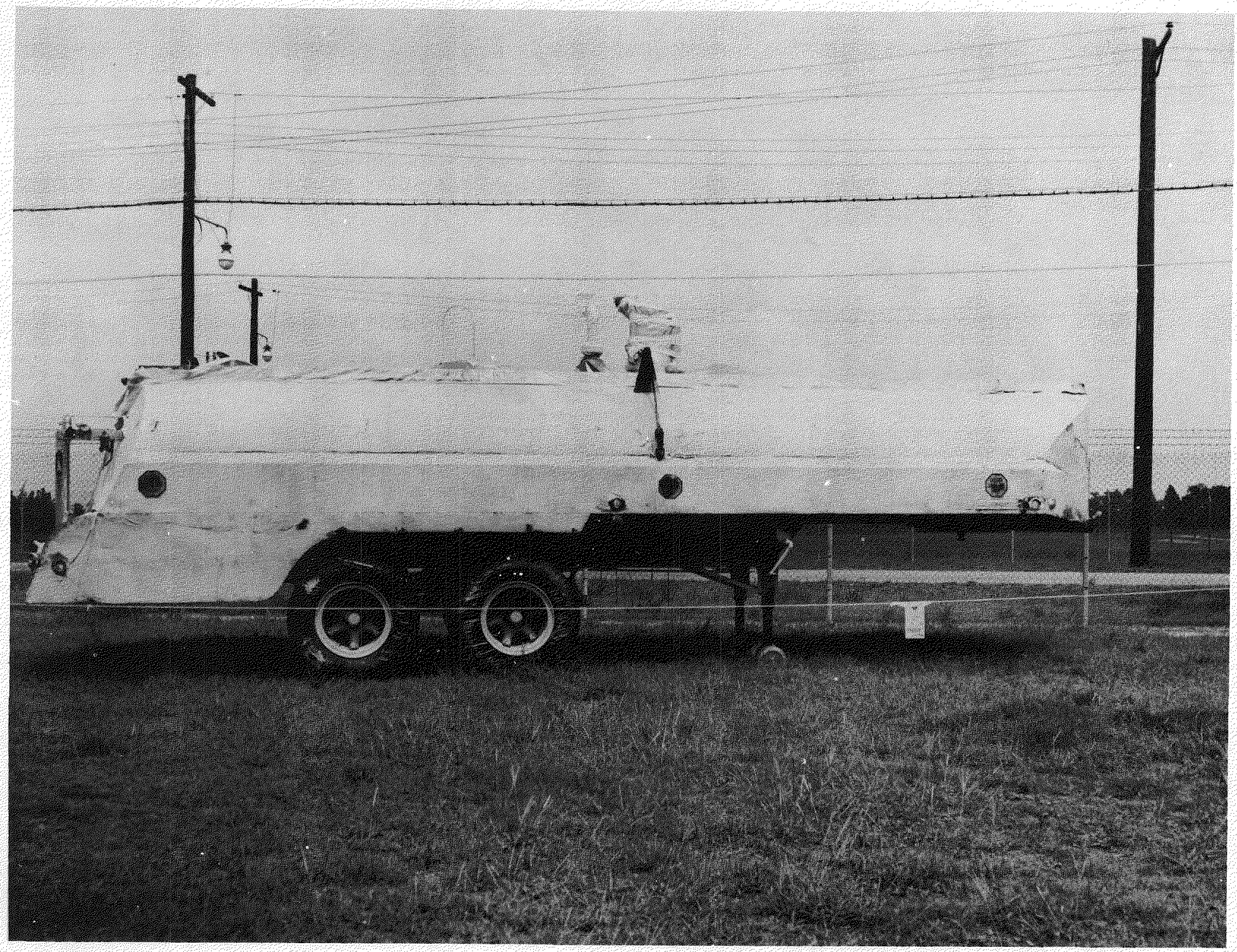

$\bullet$ 


\section{CLASS IV}

\section{CASE 2}

Description of Operation

Onsite truck shipment of radioactive wastes

Nature of Incident

Leakage; contaminated solvent spilled on roadbed

Date: April 2, 1959

Type of Radioactive Material Involved

Fission products

Radiation Consequences of the Incident

The contaminated solvent dissolved in the asphalt of the roadway.

Details of the Incident

While contaminated organic-process solvent was being transported to underground storage tanks in the burial ground, a small volume (estimated at less than one gallon) of the solvent leaked from the forward hatch of the solvent trailer and dripped onto the roadway. Approximately one-half mile of road was spot contaminated from the railroad crossing to the burial ground. Radiation levels at these spots ranged up to $8,000 \mathrm{c} / \mathrm{m}$.

Investigation of the incident has shown that the contaminated process solvent leaked out of the forward hatch cover of the tank trailer. The retaining wingnut had been replaced with an ordinary nut which, investigation showed, can slip out of place even though it appears to be properly tightened. Since the rate of radiation exposure to personnel loading the tank trailer was as high as $1,500 \mathrm{mr} / \mathrm{hr}$ and the forward hatch is seldom used, except when cleaning the tank trailer, the hatch was not inspected before the tank trailer left the area. Five loads of this solvent had already been transported to the burial ground without incident.

Nature of Injuries or Loss

It was necessary to remove a section of the asphalt roadway and replace it at a cost of $\$ 8,700$. 


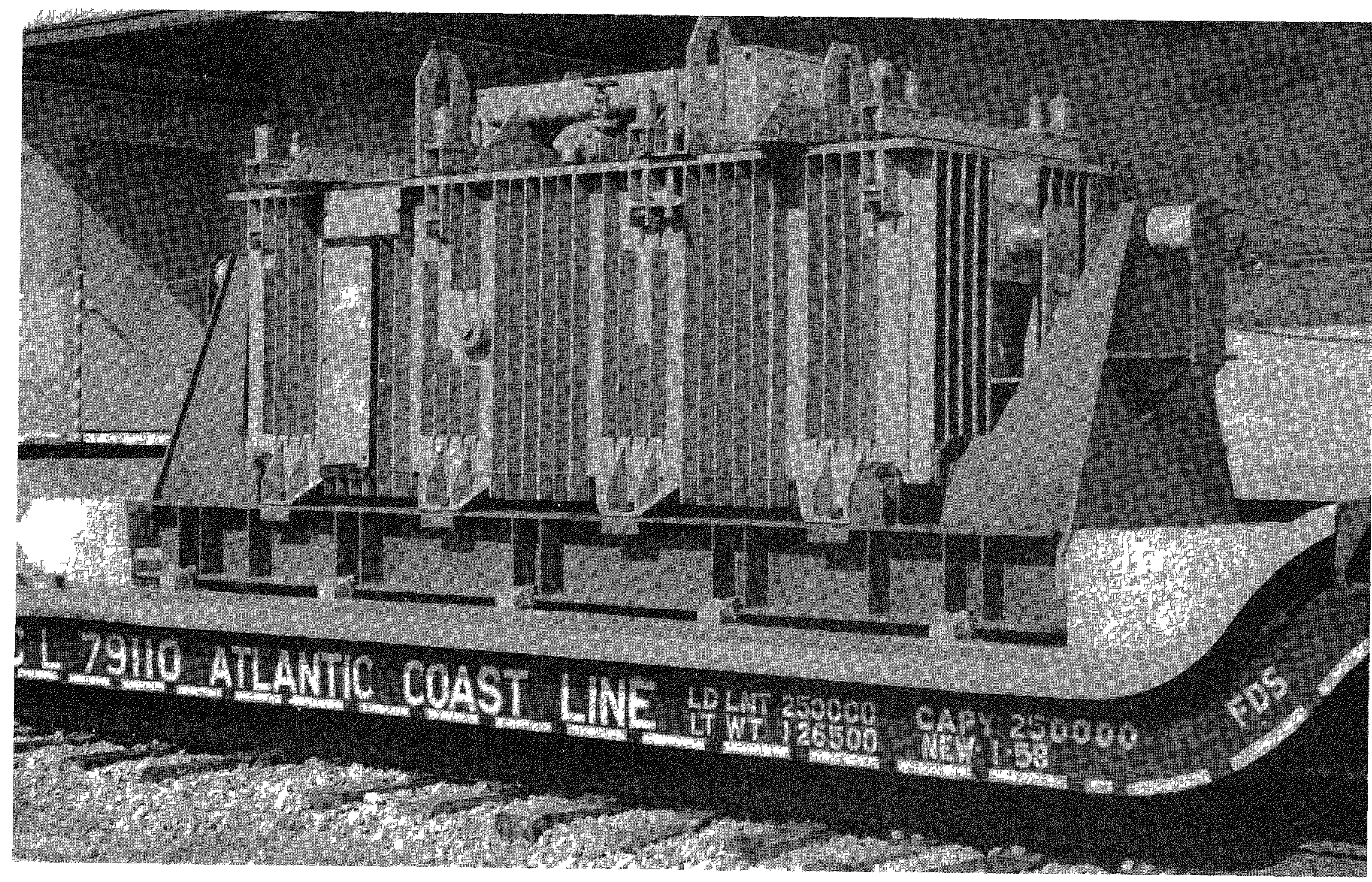




\section{CLASS IV}

\section{CASE 3}

Description of Operation

Rail shipment of irradiated fuel elements

Nature of Incident

Leakage of contaminated cooling water

Date: June 2-6, 1960

Type of Radioactive Material Involved

The shipment consisted of irradiated fuel elements containing in excess of one million curies of fission products. This particular shipment included some ruptured elements which had been encapsulated in aluminum cans.

\section{Radiation Consequences of the Incident}

The container and car were contaminated. Small areas of the railroad yards at three locations were contaminated. Earth and cinders were dug up and sent to the AEC plant, along with the shipment.

No injuries occurred.

\section{Details of the Incident}

Shortly after starting on the trip, the escorts noticed a slight amount of water dripping from the vent pipes of the coolant surge tank. However, this soon stopped, and the shipment continued. Upon arrival at a large city, it was discovered the water was again dripping from the vents, and action was taken to confine the leakage to the car. A hose and drum were obtained and a temporary arrangement was fixed so that any further leakage would be caught in the drum. Contamination to the extent of $60 \mathrm{mr} / \mathrm{hr}$ at contact was found on the ground adjacent to the track and was removed.

The shipment continued to the next rail junction, collecting about five inches of water in the drum by the time it arrived. The escorts, who had been in contact with their home office, were instructed to hold the car at this point until a radiological assistance team could arrive at the scene. The appropriate state agency was notified and representatives of the state health department inspected the area.

After the radiological assistance team arrived, the coolant surge tank was drained of seventeen gallons of water and the car and container were decontaminated. A small amount of ground (about $15 \mathrm{sq} \mathrm{ft}$ ) under the car was found to be contaminated. This was scooped out to a depth of about two inches and stored in the caboose.

Radiation levels were:

Can containing water drained from surge tank $-420 \mathrm{mr} / \mathrm{hr}$ at $2 \mathrm{in}$.

Drums containing accumulated leakage $\quad-350 \mathrm{mr} / \mathrm{hr}$ at $2 \mathrm{in}$.

Drum containing material used in de-

$$
\text { contaminating car } \quad-600 \mathrm{mr} / \mathrm{hr} \text { at } 2 \mathrm{in.}
$$


The shipment was then given clearance to continue and it proceeded to a major city without incident. Here, the leakage started again. The car was moved onto a siding, two teams were sent to the scene, and the city health department notified. More water was drained from the container, the car and right-of-way were decontaminated, and provisions were made to catch any subsequent overflow. In view of the troubles, and realizing that an appreciable amount of the coolant had been lost, it was decided to finish the trip as quickly as possible. To do this, arrangements were made with the railroad to provide a locomotive and the movement was finished by "special train" service. No further problems were encountered in transit.

Nature of Injuries or Loss

The additional direct costs incurred as a result of this incident amounted to approximately $\$ 5,000$. In addition, extra personnel time was provided by the railroads, health departments, radiological assistance teams, and plant personnel who were concerned with evaluating the problems as the shipment proceeded.

There were no injuries. 


\section{CLASS V RADIATION RELEASE}

Radioactive material is released, resulting in aerial dispersal. 


\section{CLASS $V$}

\section{CASE 1}

Description of Operation

Onsite rail shipment of contaminated equipment

Nature of Incident

Aerial dispersal of particulate contamination

Date: January 4, 1958

Type of Radioactive Material Involved

Particulate contamination, probably fission products

Radiation Consequences of the Incident

The train and the ground adjacent to the track were contaminated by airborne particulate radioactive material.

Details of the Incident

During railroad transportation of a burial box containing canyon pipe jumpers, radioactive particulate matter was shaken loose from the box, resulting in the spread of contamination along the railroad right-of-way. The diesel locomotive and several spacer cars were also contaminated.

Investigation of the incident has shown that the lid of the box, which was stored in the canyon, probably became contaminated due to the numerous crane movements over it while loading the jumpers into the box, and later this material (radioactive particulate matter) was scattered by the wind during movement of the train.

Nature of Injuries or Loss

Cost of removal of the contaminated soil and decontamination of the diesel locomotive and railroad cars was $\$ 5,200$. 


\section{CLASS VI RADIATION RELEASE}

Radioactive material is released and enters a watercourse, either directly or after spilling to the ground or trafficway. 